\title{
Reducing Endogenous $\alpha$-Synuclein Mitigates the Degeneration of Selective Neuronal Populations in an Alzheimer's Disease Transgenic Mouse Model
}

\author{
Brian Spencer, ${ }^{1}$ Paula A. Desplats, ${ }^{1,2}$ Cassia R. Overk, ${ }^{1}$ Elvira Valera-Martin, ${ }^{1}$ Robert A. Rissman, ${ }^{1}$ Chengbiao Wu,${ }^{1}$ \\ Michael Mante, ${ }^{1}$ Anthony Adame, ${ }^{1}$ Jazmin Florio, ${ }^{1}$ Edward Rockenstein, ${ }^{1}$ and Eliezer Masliah ${ }^{1,2}$ \\ ${ }^{1}$ Department of Neurosciences and ${ }^{2}$ Department of Pathology, University of California-San Diego, La Jolla, California 92093
}

\begin{abstract}
Alzheimer's disease (AD) is characterized by the progressive accumulation of amyloid $\beta(\mathrm{A} \beta)$ and microtubule associate protein tau, leading to the selective degeneration of neurons in the neocortex, limbic system, and nucleus basalis, among others. Recent studies have shown that $\alpha$-synuclein ( $\alpha$-syn) also accumulates in the brains of patients with $\mathrm{AD}$ and interacts with $\mathrm{A} \beta$ and tau, forming toxic hetero-oligomers. Although the involvement of $\alpha$-syn has been investigated extensively in Lewy body disease, less is known about the role of this synaptic protein in AD. Here, we found that reducing endogenous $\alpha$-syn in an APP transgenic mouse model of AD prevented the degeneration of cholinergic neurons, ameliorated corresponding deficits, and recovered the levels of Rab3a and Rab5 proteins involved in intracellular transport and sorting of nerve growth factor and brain-derived neurotrophic factor. Together, these results suggest that $\alpha$-syn might participate in mechanisms of vulnerability of selected neuronal populations in $\mathrm{AD}$ and that reducing $\alpha$-syn might be a potential approach to protecting these populations from the toxic effects of $A \beta$.
\end{abstract}

Key words: $\alpha$-synuclein; Alzheimer's disease; amyloid $\beta$ oligomer; cholinergic neuron; selective vulnerability; transgenic animal model

Significance Statement

Reducing endogenous $\alpha$-synuclein ( $\alpha$-syn) in an APP transgenic mouse model of Alzheimer's disease (AD) prevented the degeneration of cholinergic neurons, ameliorated corresponding deficits, and recovered the levels of Rab3a and Rab5 proteins involved in intracellular transport and sorting of nerve growth factor and brain-derived neurotrophic factor. These results suggest that $\alpha$-syn might participate in mechanisms of vulnerability of selected neuronal populations in AD and that reducing $\alpha$-syn might be a potential approach to protecting these populations from the toxic effects of amyloid $\beta$.

\section{Introduction}

Alzheimer's disease (AD) is an heterogeneous neurodegenerative disorder (Schellenberg, 1995; Komarova and Thalhauser, 2011; Lam et al., 2013) that affects $>5$ million in the United States alone (Alzheimer's Association, 2015) and is characterized by the progressive accumulation of amyloid $\beta(\mathrm{A} \beta)$ and microtubule associated protein tau ( $\mathrm{Tau}$ ), leading to the selective degeneration of neurons in the neocortex, limbic system, and nucleus basalis,

Received March 8, 2016; revised June 8, 2016; accepted June 13, 2016.

Author contributions: B.S., P.A.D., R.A.R., C.W., and E.M. designed research; B.S., P.A.D., C.R.O., E.V.-M., R.A.R., C.W., M.M., A.A., J.F., E.R., and E.M. performed research; R.A.R., C.W., and E.M. analyzed data; B.S., P.A.D., C.R.O., R.A.R., C.W., and E.M. wrote the paper.

This work was supported by the National Institutes of Health (Grants AG18840, AG022074, and AG10435). The authors declare no competing financial interests.

Correspondence should be addressed to Dr. E. Masliah, Department of Neurosciences, University of California, 9500 Gilman Drive, La Jolla, CA 92093-0624. E-mail: emasliah@ucsd.edu.

DOI:10.1523/JNEUROSCI.0775-16.2016

Copyright $\odot 2016$ the authors $\quad 0270-6474 / 16 / 367971-14 \$ 15.00 / 0$ among others (Morrison and Hof, 2002; Saxena and Caroni, 2011; Mattsson et al., 2016). In addition to $\mathrm{A} \beta$ and Tau, recent studies have shown that $\alpha$-synuclein ( $\alpha$-syn) (Hansen et al., 1990; McKeith, 2006; Lippa et al., 2007; Larson et al., 2012; Winslow et al., 2014; Walker et al., 2015) and TAR DNA-binding protein (TDP)-43 (Wilson et al., 2011; Colom-Cadena et al., 2013; Borchelt et al., 2014) might also contribute to the pathogenesis of $\mathrm{AD}$. The mechanisms leading to the accumulation of multiple proteins in $\mathrm{AD}$ are not completely understood, but defective protein clearance, including alterations in autophagy (Lucin and Wyss-Coray, 2013; Nixon, 2013; Peric and Annaert, 2015; ZareShahabadi et al., 2015) and proteolysis of aggregates (Borchelt et al., 2014), might be centrally involved.

$\alpha$-syn has been investigated extensively in other neurodegenerative disorders such as Parkinson's disease (PD) and dementia with Lewy bodies (DLB) (Takeda et al., 1998; Piao et al., 2000; Spillantini and Goedert, 2016); however, less is known about its role as a synaptic protein in AD. Previous studies have shown that 
the pathology of AD and PD overlap (Hansen et al., 1990; McKeith, 2006; Lippa et al., 2007; Winslow et al., 2014; Walker et al., 2015). In AD and in APP transgenic (Tg) models, $\alpha$-syn interacts with $\mathrm{A} \beta$ (Tsigelny et al., 2008) and Tau (Giasson et al., 2003; Esposito et al., 2007; Clinton et al., 2010) and accumulates in selected regions of the limbic system in patients with $\mathrm{AD}$ (Swirski et al., 2014), including dystrophic neurites and synapses around the $\mathrm{A} \beta$ plaques (Masliah et al., 1996). A $\beta$ promotes $\alpha$-syn aggregation and toxicity (Masliah et al., 2001), and they have synergistic effects leading to synaptic dysfunction (Wang et al., 2015). In patients with $\mathrm{AD}$, levels of soluble $\alpha$-syn are elevated in brain and fluids, which differs from PD (Larson et al., 2012; Tateno et al., 2012). Moreover, recent studies showed that, in APP Tg mice, $\alpha$-syn infusion reduces A $\beta$ plaque formation but enhances synaptic degeneration (Bachhuber et al., 2015) and that $\mathrm{A} \beta$ and $\alpha$-syn cooperated to block SNARE-vesicle fusion (Choi et al., 2015). This is of interest given the role of $\alpha$-syn in regulating intracellular vesicle trafficking via interactions with Rab3 and Rab8 (Cooper et al., 2006).

Furthermore, we have shown that coexpression of human $\alpha$-syn in APP Tg mice results in enhanced degeneration of cholinergic neurons in the nucleus basalis (Masliah et al., 2001) and glutamatergic neurons in the CA3 region of the hippocampus (Overk et al., 2014). Here, we found that reducing endogenous $\alpha$-syn levels in an APP mouse model of AD prevented the degeneration of cholinergic neurons, ameliorated functional deficits, and normalized levels of Rab3a and Rab5 proteins involved in intracellular transport and sorting of nerve growth factor (NGF) and brain-derived neurotrophic factor (BDNF). These findings also support the notion that $\alpha$-syn is an important contributor to $\mathrm{AD}$ pathogenesis and that regulating $\alpha$-syn might be of therapeutic value in $\mathrm{AD}$.

\section{Materials and Methods}

Crosses between mThy1-APP Tg mice and $\alpha$-syn knock-out (KO) mice. The University of California at San Diego Institutional Animal Care and Use Committee approved all animal experiments. For these experiments, mice expressing human APP751 cDNA containing the London (V717I) and Swedish (K670M/N671L) mutations under the regulatory control of the murine (m)Thy-1 gene (mThyl-hAPP751; line 41) on a C57BL/6 background were used (Rockenstein et al., 2001). These mice display early $\mathrm{A} \beta$ deposition, behavioral deficits, and degeneration of the limbic and cholinergic systems (Havas et al., 2011). These APP Tg mice were then crossbred with homozygous $\alpha$-syn ${ }^{-1-}$ mice (129X1/SvJ strain of origin) obtained from The Jackson Laboratory (ID:003692). $\alpha$-syn KO mice containing a PGK neocassette in place of the $\alpha$-syn exons 3-7 have been described previously (Abeliovich et al., 2000).

Tissue preparation. Following National Institutes of Health guidelines for the humane treatment of animals, mice were anesthetized with chloral hydrate and flush-perfused transcardially with $0.9 \%$ saline. Brains were removed and divided in sagittal sections. The right hemibrain was postfixed in phosphate-buffered $4 \% \mathrm{PFA}, \mathrm{pH} 7.4$, at $4^{\circ} \mathrm{C}$ for $48 \mathrm{~h}$ for neuropathological analysis and the left hemibrain was snap-frozen and stored at $-70^{\circ} \mathrm{C}$ for subsequent RNA and protein analysis.

Water maze testing. To evaluate the functional effects of ablating $\alpha$-syn, groups of male and female APP Tg, $\alpha$-syn KO, APP Tg/ $\alpha$-syn KO, and non-Tg animals were tested in the water maze, as described previously (Rockenstein et al., 2005). For this purpose, a pool (diameter $180 \mathrm{~cm}$ ) was filled with opaque water $\left(24^{\circ} \mathrm{C}\right)$ and mice were first trained to locate a visible platform (days 1-3) and then a submerged hidden platform (days $4-7$ ) in 3 daily trials $2-3 \mathrm{~min}$ apart. Mice that failed to find the hidden platform within $90 \mathrm{~s}$ were directed to the platform and allowed to remain there for $30 \mathrm{~s}$. The same platform location was used for all sessions. The starting point at which each mouse was placed into the water was changed randomly between two alternative entry points located at a similar distance from the platform. Time to reach the platform (latency) and entrances into target quadrant were recorded with a Noldus Instruments EthoVision video tracking system set to analyze two samples per second. All experimental conditions were the same for the probe test except the platform was removed and the amount of time spent in the quadrant that previously contained the platform was recorded. For these experiments, mice were 4-6 months old to avoid widespread amyloid deposition, which occurs in older mice, as a compounding factor $(n=10$ mice/ group, half male and half female).

Behavioral testing in the open field. The open field locomotor test was used to determine basal activity levels of study subjects (total move time) during a $15 \mathrm{~min}$ session. Spontaneous activity in an open field $(25.5 \times$ $25.5 \mathrm{~cm}$ ) was monitored for $15 \mathrm{~min}$ using an automated system (Truscan system for mice; Coulbourn Instruments). Animals were tested within the first $2-4 \mathrm{~h}$ of the dark cycle after being habituated to the testing room for $15 \mathrm{~min}$. The open field was illuminated with an anglepoise lamp equipped with a $25 \mathrm{~W}$ red bulb. Animals were tested at 4-6 months of age. Time spent in motion was automatically collected in $3 \times 5$ min time bins using TruScan software. Data were analyzed for both the entire 15 min session and for each of the 5 min time blocks.

Quantitative PCR. Total RNAs were extracted from mice brains using RNeasy Lipid mini kit (Qiagen) and reverse transcribed using SuperScript VILO cDNA synthesis kit (Life Technologies), respectively, as described previously (Kim et al., 2015). Quantitative real-time PCR was performed using TaqMan Fast Advanced Master Mix (Life Technologies) according to the manufacturer's instructions with gene specific primers for Rab3. Amplification of DNA products was measured by the StepOnePlus real-time PCR system (Applied Biosystems). Relative mRNA levels were calculated according to the 2-exp (ddCt) method (Kim et al., 2015). All dCT values were normalized to $\beta$-actin.

Immunohistochemical analysis. Analysis was performed using freefloating, $40 \mu \mathrm{m}$-thick, vibratome-cut, blind-coded sections, as described previously (Zwilling et al., 2011; Games et al., 2013). Briefly, sections were incubated overnight at $4^{\circ} \mathrm{C}$ with antibodies against total $\alpha$-syn (1: 500, affinity-purified rabbit polyclonal, Millipore; Masliah et al., 2000), A $\beta$ (6E10, mouse monoclonal; BioLegend), ChAT (1:500, affinitypurified monoclonal; Millipore), parvalbumin (1:500, affinity-purified monoclonal; Millipore), calbindin (1:500, polyclonal; Millipore), neuropeptide Y (NPY; 1:500, affinity-purified polyclonal; Millipore), NeuN (1:500, affinity-purified monoclonal; Millipore), GFAP (1:500, affinitypurified monoclonal; Millipore), Rab3a (1:500, polyclonal; Abcam), Rab5 (1:500, polyclonal; Santa Cruz Biotechnology), Rab7 (1:500, monoclonal; Abcam), Rab7 (1:500 monoclonal; Millipore), and Rab11 (1:500, polyclonal; Millipore), followed by biotin-tagged anti-rabbit or anti-mouse IgG1 (1:100; Vector Laboratories) secondary antibodies, avidin D-HRP (1:200, ABC Elite; Vector Laboratories), and visualized with diaminobenzidine (DAB). Sections were scanned with a digital Olympus bright-field digital microscope (BX41).

Sections immunoreacted with antibodies against Rab3a and Rab5 were visualized with FITC-tagged secondary antibody or the Tyramide Signal Amplification Direct (Red) system (1:100; NEN Life Sciences), respectively, mounted under glass coverslips with anti-fading media (Vector Laboratories), and imaged with a laser scanning confocal microscope (LSCM) (MRC1024; Bio-Rad).

Image analysis and stereology. Sections immunostained with antibodies against $\alpha$-syn, APP/A $\beta$, GFAP, Rab7, and Rab11 were analyzed with a digital Olympus bright-field digital microscope (BX41). For each case, a total of three sections (four digital images per section at $400 \times$ magnification) were obtained from the frontal cortex and hippocampus and analyzed as described previously with ImageJ to obtain optical density, with levels were corrected to background. The numbers of NeuNimmunoreactive neurons were estimated using unbiased stereological methods (Overk et al., 2009). Hemisections containing the neocortex, hippocampus, and striatum were outlined using an Olympus BX51 microscope running StereoInvestigator 8.21.1 software (MicroBrightField). Grid sizes for the hippocampal CA3 and CA1 pyramidal layers were as follows: $300 \times 300 \mu \mathrm{m}$ and the counting frames were and $50 \times 50 \mu \mathrm{m}$, respectively. The average coefficient of error for each region was 0.9 . Sections were analyzed using a $100 \times 1.4$ PlanApo oil-immersion 
objective. A 5- $\mu \mathrm{m}$-high dissector allowed for $2 \mu \mathrm{m}$ top and bottom guard zones.

Sections immunolabeled with antibodies against Rab3a and Rab5 were serially imaged with the LSCM (MRC1024; Bio-Rad) and analyzed with ImageJ, as described previously (Masliah et al., 2011). For each mouse, a total of three sections were analyzed and, for each section, four fields in the CA1 and CA 3 of the hippocampus were examined. Results are expressed as pixel intensities.

Immunoblot analysis. The levels of $\alpha$-syn, $\mathrm{A} \beta$, APP, Rabs, pro-NGF/ NGF, and pro-BDNF/BDNF in hippocampus and cortex from mouse brains were analyzed using lysates that were extracted and fractioned into membrane and cytosolic fractions by ultracentrifugation (Masliah et al., 2011). Protein (20 $\mu \mathrm{g} /$ lane) was loaded onto $4-12 \%$ SDS/PAGE gels and blotted onto PVDF membranes, and incubated with specific antibodies, followed by HRP-tagged secondary antibodies (1:5000; Santa Cruz Biotechnology). Bands were visualized by enhanced chemiluminescence (PerkinElmer) and analyzed with a quantitative Versadoc XL imaging apparatus (Bio-Rad). $\beta$-actin (1:3000) was the loading control.

Construction of lentivirus vectors. The sh $\alpha$-syn (GAC TTT CAA AGG CCA AGG A) was cloned into the pSI-H1-copGFP vector (SBI Vector) containing the $\mathrm{H} 1$ promoter. The control shRNA lentivector (LV-shLuc) contains an shRNA directed against firefly luciferase (SBI Vector). The lentivirus plasmid-expressing mouse Rab3a (plenti6/CMV V5mCherry mouse Rab3a) was provided by CEDOC/ Universidade Nova de Lisboa. Lentiviruses expressing Rab3, sh $\alpha$-syn, sh-luciferase, or empty vector (as controls) were prepared by transient transfection in 293T cells. Lentivirus vectors were prepared by transient transfection of the three packaging plasmids and the vector plasmid in $293 \mathrm{~T}$ cells as described previously (Tiscornia et al., 2006; Spencer et al., 2009) and titers were obtained by ELISA.

Neuronal cell line treatments, lentiviral vectors, and analysis. The mouse cholinergic cell line Neuro2A (N2A) was used for in vitro experiments (Klebe and Ruddle, 1969). N2A cells were infected with LV-control, LVsh $\alpha$-syn, or LV-Rab3a at a multiplicity of infection of 50 for $48 \mathrm{~h}$ and then plated at $1 \times 10^{5}$ cells/well on poly-L-lysine-coated coverslips in DMEM $+1 \%$ FBS for $5 \mathrm{~d}$ to allow for differentiation. Cells were treated with $5 \mathrm{nM}$ $\mathrm{A} \beta$ oligomers (American Peptide) for $24 \mathrm{~h}$ (Tsigelny et al., 2014) and then fixed in $4 \%$ paraformaldehyde and analyzed by immunocytochemistry for the expression of $\alpha$-syn (Millipore), Rab3a (polyclonal; Abcam), Rab5 (monoclonal; Cell Signaling Technology), and ChAT (polyclonal; Millipore), as described above. ChAT was detected with DAB and analyzed by bright-field microscopy. $\alpha$-syn and Rab5 were detected with Tyramide Red (NEN Life Sciences) and Rab3a with FITC and analyzed by laser scanning confocal microscopy (Bio-Rad, MRC1024).

N2A cells were double immunolabeled with antibodies against tubulin III (monoclonal; Millipore) and NGF (polyclonal Millipore). NGF was detected with the Tyramide Red (NEN Life Sciences), whereas tubulin III was detected with FITC-tagged antibodies (1:75; Vector Laboratories). Coverslips were imaged with a Zeiss $63 \times 1.4$ objective on an Axiovert 35 microscope (Zeiss) with an attached MRC1024 LSCM system (Bio-Rad) (Masliah et al., 2011) and analyzed with ImageJ to determine colocalization (Nuber et al., 2014).

Statistical analysis. All analyses were performed using GraphPad Prism (version 5.0) software. Differences among means were assessed by oneway ANOVA with Dunnett's post hoc test when compared with non-Tg and by Tukey-Kramer when comparing Tg groups. Two-way ANOVA with repeated measures followed by a Bonferroni multiple-comparisons post hoc test was used for analyzing the interactions between groups and time. Linear regression analysis with Pearson's correlation coefficient was performed for analyzing interactions between CA3 neurons, ChAT immunoreactivity in the hippocampus, and behavioral data. The null hypothesis was rejected at the 0.05 level.

\section{Results}

Reducing endogenous $\alpha$-syn has no effects on APP expression or $\mathrm{A} \boldsymbol{\beta}$ deposition in APP Tg mice

To understand the contribution of $\alpha$-syn to the pathogenesis of AD, mThy-1 APP (line 41) mice were crossed with $\alpha$-syn KO mice (Fig. 1A). Immunoblot analysis showed comparable levels of endogenous APP between the non-Tg and the $\alpha$-syn KO mice. The APP Tg mice, which over express hAPP in addition to endogenous expression of APP, had similar levels of total APP and $\mathrm{A} \beta$ compared with the APP $\mathrm{Tg} / \alpha$-syn $\mathrm{KO}$ mice (Fig. $1 B-D$ ), which was significantly increased compared with non-Tg mice. Compared with the non-Tg mice, the APP Tg mice showed a $30 \%$ increase in $\alpha$-syn (Fig. $1 B, E$ ); no endogenous $\alpha$-syn was detected in the $\alpha$-syn KO and APP Tg/ $\alpha$-syn KO mice (Fig. $1 B, E$ ). Immunocytochemical analysis for total APP (Fig. $1 F, G$ ) and total $\alpha$-syn (Fig. $1 H, I$ ) were in agreement with the immunoblot analysis (Fig. $1 B$ ). Next, we analyzed levels of $\mathrm{A} \beta$ deposition and proteinase $\mathrm{K}(\mathrm{PK})$-resistant $\alpha$-syn aggregates with antibodies against $\mathrm{A} \beta$ and $\alpha$-syn, respectively. The APP Tg and the APP Tg/ $\alpha$-syn $\mathrm{KO}$ mice displayed similar levels of $\mathrm{A} \beta$ deposition in the neocortex and hippocampus (Fig. 2A,B). Compared with the non-Tg, the APP Tg mice showed increased accumulation of PK-resistant $\alpha$-syn (Fig. 2C,D).

\section{$\alpha$-syn knock-down ameliorates the degeneration of cholinergic fibers and hippocampal neurons in APP Tg mice}

We have shown previously that $\alpha$-syn interacts with $\mathrm{A} \beta$, resulting in the degeneration of cholinergic (Masliah et al., 2001) and hippocampal neurons (Overk et al., 2014); moreover, $\alpha$-syn reduction has been shown to protect dopaminergic neurons from chemical insults (Drolet et al., 2004; Javed et al., 2015). For this reason, we next investigated whether knocking down $\alpha$-syn might protect selective neuronal populations from the neurotoxic effects of $\mathrm{A} \beta$. Analysis of the cholinergic system with an antibody against ChAT showed that, compared with non-Tg and $\alpha$-syn KO mice, the APP Tg mice displayed a reduction in the cholinergic innervation of the molecular layer of the dentate gyrus of the hippocampus (Fig. $3 A, B$ ). In contrast, the APP Tg/ $\alpha$-syn KO mice showed cholinergic fiber density in the hippocampus that was significantly increased compared with APP Tg mice (Fig. $3 A, B$ ). Compared with non-Tg controls, APP Tg mice displayed a trend toward decreased cholinergic neurons in the nucleus basalis; however, no significant differences were seen among the groups (Fig. $3 A, C$ ). Given that $\alpha$-syn participates in the degeneration of the dopaminergic system and that, in APP Tg mice, there is a mild increase in $\alpha$-syn, we next investigated the dopaminergic system with an antibody against tyrosine hydroxylase. However, levels of dopaminergic fibers in the striatum (Fig. $3 D, E$ ) and numbers of cells in the midbrain (Fig. $3 D, F$ ) were similar among the four groups.

Next, we analyzed the effects of knocking down $\alpha$-syn in APP mice on the degeneration of neuronal populations in the hippocampus. Consistent with previous reports (Overk et al., 2014) and compared with non-Tg controls, the APP Tg mice displayed neuronal loss in the CA3 area of the hippocampus (Fig. 4A,B). Remarkably, the APP Tg/ $\alpha$-syn KO mice showed neuronal density in the CA3 comparable to the non-Tg controls (Fig. 4A,B). However, compared with non-Tg and $\alpha$-syn KO mice, both APP $\mathrm{Tg}$ and $\mathrm{APP} \mathrm{Tg} / \alpha$-syn $\mathrm{KO}$ mice displayed increased astrogliosis in the hippocampus (Fig. 4C,D).

Previous studies have shown that the network dysfunction and degeneration in the hippocampus is accompanied by hyperinnervation by NPY fibers (Palop et al., 2007). In agreement with these studies and compared with non-Tg controls, the APP Tg mice displayed increased innervation by NPY-positive fibers in the molecular layer of dentate gyrus of the hippocampus (Fig. $5 A, B)$. In contrast, in the $\alpha$-syn KO background, the APP Tg mice showed innervation by NPY positive fibers comparable to 
A

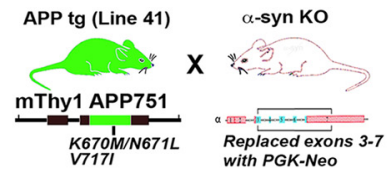

B

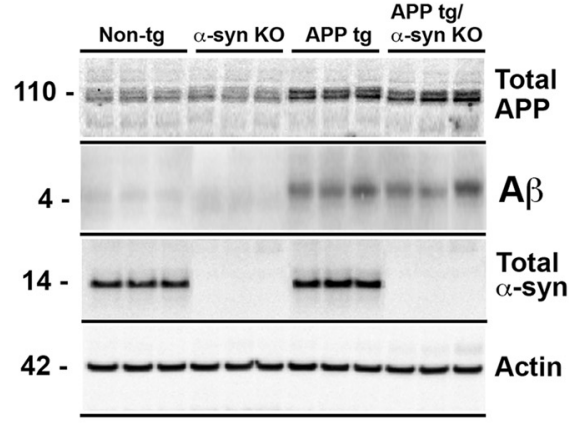

F

F
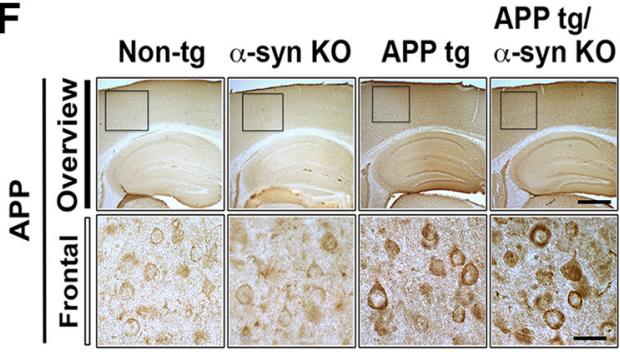

H

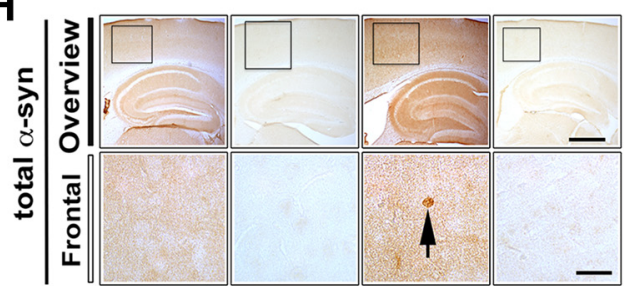

C

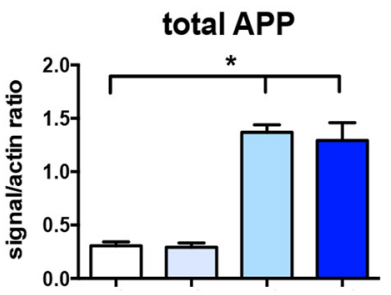

E

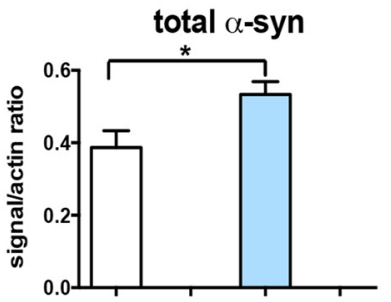

G
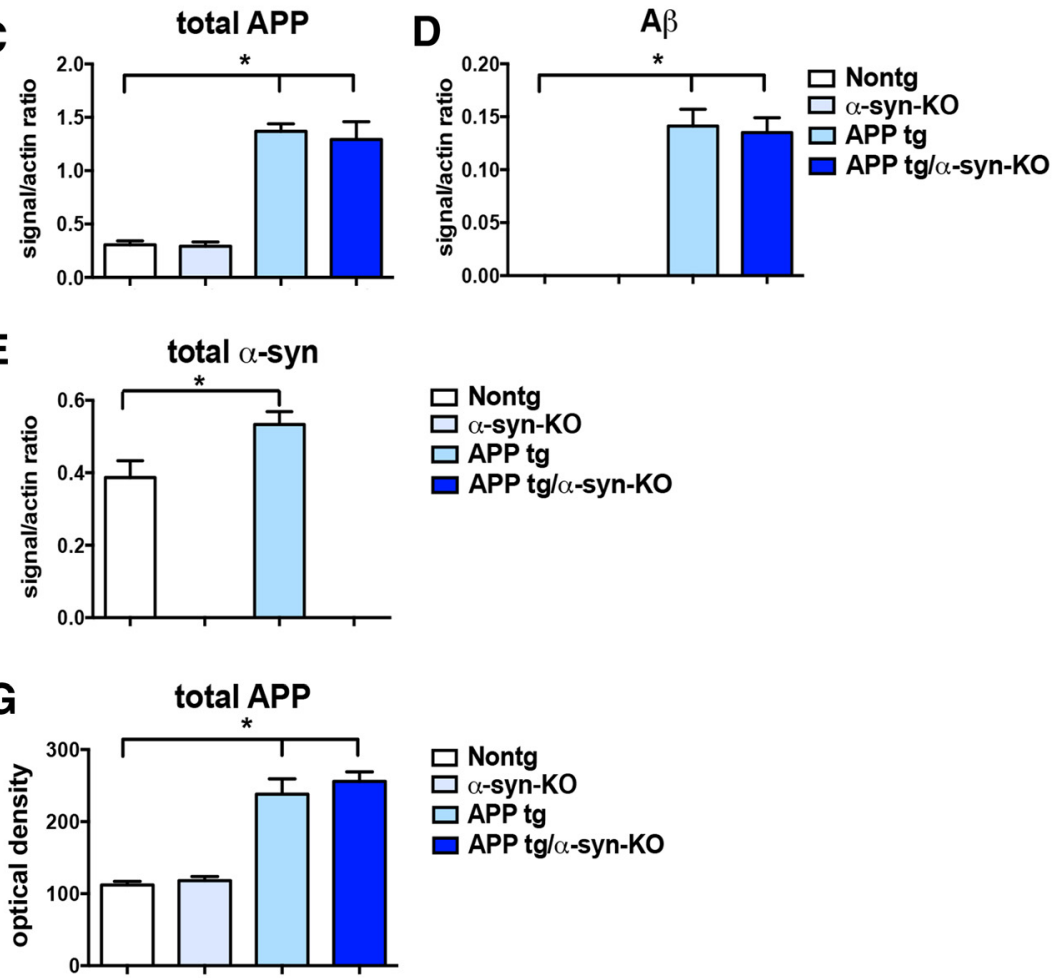

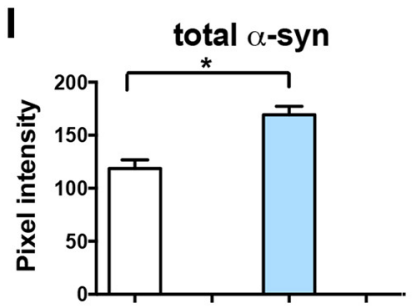

Figure 1. Generation and characterization of Tg mice expressing APP or APP under the mThy 1 promoter in the absence of endogenous $\alpha$-syn. $\boldsymbol{A}$, Schematic representation of the APP single Tg mice (line 41) and $\alpha$-syn K0 mice. $B$, Representative Western blot of total APP (doublet $\sim 110 \mathrm{kDa}$ ), A $\beta$ (4 kDa), and total $\alpha$-syn (monomer $14 \mathrm{kDa}$ ) in the membrane fraction in non-Tg, $\alpha$-syn K0, APP Tg, and APP Tg/ $\alpha$-syn KO mice. C, D, Computer-aided analysis of the immunoblot for total APP and A $\beta$ showing that the levels of endogenous APP protein were comparable between non-Tg and $\alpha$-syn KO mice and between APP Tg and APP Tg/ $\alpha$-syn KO mice. $\boldsymbol{E}$, Computer-aided analysis of the immunoblot for total $\alpha$-syn showing that no endogenous $\alpha$-syn was detected in either the $\alpha$-syn KO or APP Tg/ $\alpha$-syn KO mouse lines compared with non-Tg mice. APP Tg mice had a significant increase in the level of endogenous $\alpha$-syn protein. $F$, Representative photomicrographs of the hippocampus, frontal cortex, and magnified frontal cortex immunoreacted with an antibody against total APP in non-Tg, $\alpha$-syn K0, APP Tg, and APP Tg / $\alpha$-syn K0 mice. G, Computer-aided image analysis indicated that total APP was significantly increased in APP Tg and APP Tg/ $\alpha$-syn KO mice compared with non-Tg mice. $\boldsymbol{H}$, Representative photomicrographs of the hippocampus, frontal cortex, and magnified frontal cortex immunoreacted with an antibody against total $\alpha$-syn in non-Tg, $\alpha$-syn K0, APP Tg, and APP Tg / $\alpha$-syn K0 mice. Arrow indicates $\alpha$-syn aggregate. $I$, Computer-aided image analysis indicated that total $\alpha$-syn was undetectable in $\alpha$-syn K0 and APP Tg/ $\alpha$-syn K0 mice compared with non-Tg mice. APP Tg mice had a significant increase in total $\alpha$-syn compared with non-Tg mice. * $p<0.05$ by one-way ANOVA and Dunnett's post hoc analysis. For analysis, 10 mice $4-6$ months of age were used. Scale bars, $200 \mu m$ in low-power images and $40 \mu \mathrm{m}$ in high-power images.

the non-Tg controls (Fig. 5A,B). The numbers of NPY-positive cells in the CA3 of the hippocampus was unchanged among the four groups (Fig. $5 \mathrm{~A}, \mathrm{C}$ ). As part of this network, dysfunction and degeneration of the hippocampus previous studies have shown that calbindin neurons in the dentate gyrus are reduced in $\mathrm{AD}$ and APP Tg mice (Palop et al., 2007). We found decreased levels of calbindin in APP Tg mice, with no recovery detected in the APP $\mathrm{Tg} / \alpha$-syn KO mice compared with non-Tg mice (Fig. $5 D, E)$. Other populations of interneurons, including those identified with an antibody against parvalbumin, were unchanged among the four groups of mice (Fig. 5D,F).

Together, these studies suggest that knocking down $\alpha$-syn ameliorates the degeneration of the cholinergic fibers and CA3 neurons in the hippocampus, but has no effect on preventing the loss of calbindin neurons.
Lowering levels of endogenous $\alpha$-syn ameliorates behavioral deficits in APP Tg mice

To evaluate the functional effects of preventing the degeneration of selective neuronal populations in APP Tg/ $\alpha$-syn $\mathrm{KO}$ mice, behavioral analysis was performed in the water maze and open field (Fig. 6). In the training portion of the test in the water maze with the platform visible (days 1-3). all four groups of mice performed similarly (Fig. 6A). In the hidden platform portion of the test (days 4-7), the APP Tg mice displayed deficient spatial learning compared with non-Tg and $\alpha$-syn $\mathrm{KO}$, whereas APP Tg/ $\alpha$ syn $\mathrm{KO}$ mice performed comparable to controls (Fig. $6 A$ ). In the probe portion of the test on day 8, compared with non-Tg and $\alpha$-syn KO, both the APP Tg and APP Tg/ $\alpha$-syn KO mice displayed deficits (Fig. 6B). No differences among the four groups of animals were observed in the other three quadrants (Fig. 6C-E). 
A
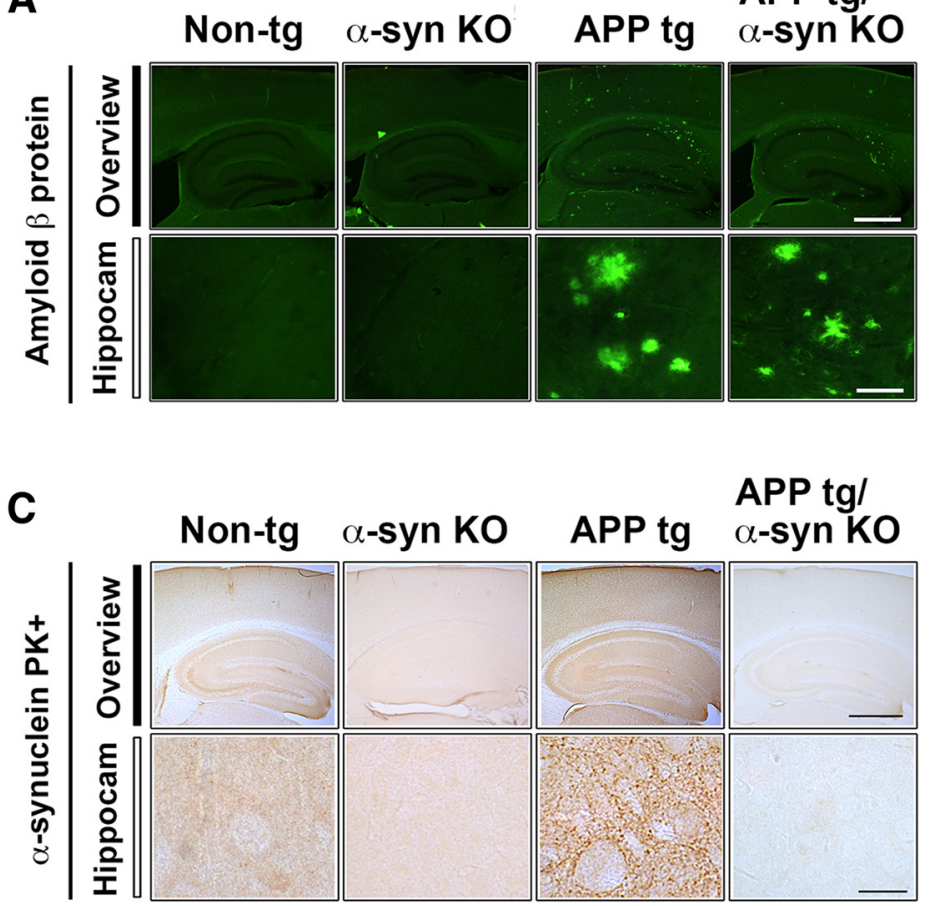

B
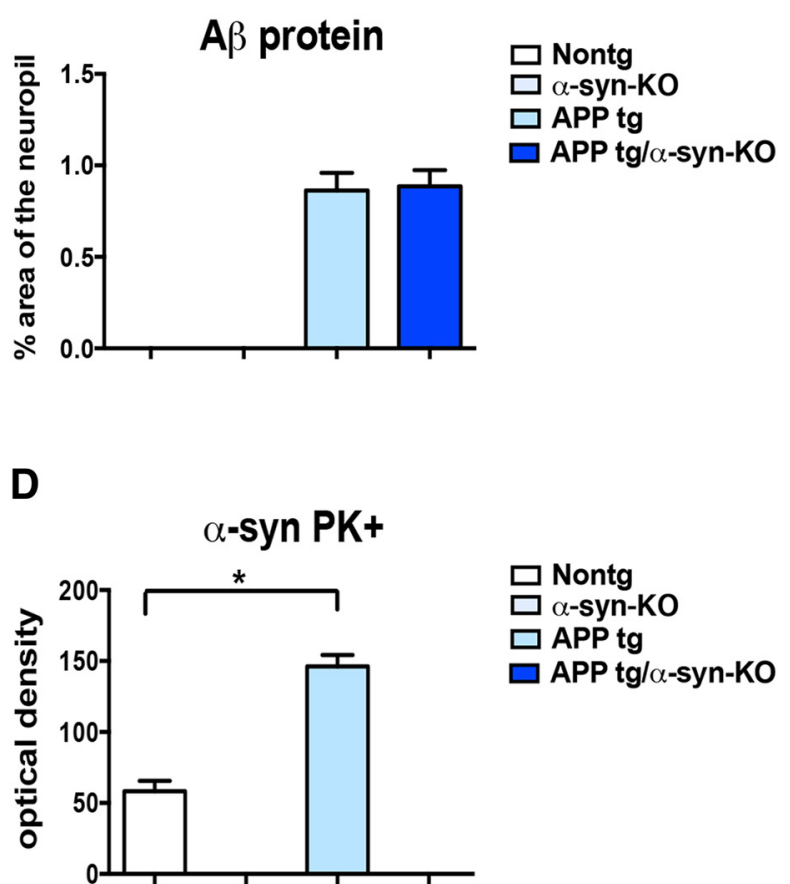

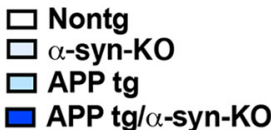

Figure 2. Comparison of the patterns of A $\beta$ and PK-resistant $\alpha$-syn accumulation in the hippocampus of APP and APP Tg/ $\alpha$-syn K0. For these experiments, non-Tg, APP Tg, $\alpha$-syn K0, and APP $\mathrm{Tg} / \alpha$-syn KO mice were used. $A$, Representative low-magnification photomicrographs of the hippocampus and neocortex using vibratome sections immunostained with antibody against A $\beta$ from non-Tg, APP Tg, $\alpha$-syn K0, and APP Tg/ $\alpha$-syn KO mice. Second row shows representative high-magnification photomicrographs of the hippocampus. $\boldsymbol{B}$, Corrected optical densitometry analysis of the hippocampal CA3 region revealed that A $\beta$ aggregates were comparable between APP $\mathrm{Tg}$ and APP $\mathrm{Tg} / \alpha$-syn $\mathrm{KO}$ mice. A $\beta$ protein aggregates were not detected in the non-Tg and $\alpha$-syn K0 mouse lines. C, Representative low-magnification photomicrographs of the CA3 and CA1 regions of the hippocampus using vibratome sections pretreated with PK and immunostained with rabbit polyclonal antibody against full-length total $\alpha$-syn (Millipore) from non-Tg, APP Tg, $\alpha$-syn K0, and APP Tg/ $\alpha$-syn K0 mice. Second row shows high-magnification photomicrographs from the hippocampus. Endogenous PK-resistant $\alpha$-syn was observed in a punctate pattern in the neuropil of CA1 and CA3 in the non-Tg and was significantly increased in APP Tg mice. PK-resistant $\alpha$-syn was undetectable in the $\alpha$-syn KO and APP Tg/ $\alpha$-syn KO mice. D, Corrected optical densitometry analysis of the hippocampal CA3 region revealed that PK-resistant $\alpha$-syn was significantly enhanced in the APP Tg mice compared with non-Tg mice $\alpha$-syn and $\alpha$-syn was undetectable in the $\alpha$-syn K0 and APP Tg/ $\alpha$-syn KO mouse lines. Statistical analysis was conducted using one-way ANOVA post hoc Dunnett's test for comparison with non-Tg mice $\left(^{*}\right)$. For analysis, 10 mice $4-6$ months of age were used. Scale bars, $200 \mu \mathrm{m}$ in low-power images and $40 \mu \mathrm{m}$ in high-power images.

In addition to the learning and memory deficits in the water maze, the APP Tg mice showed hyperactivity in the open field paradigm compared with non-Tg mice (Fig. 6F). Knocking down $\alpha$-syn in the APP mice normalized their total activity without affecting rearing (Fig. $6 F, G$ ). Together, these results suggests that reducing endogenous $\alpha$-syn rescues hyperactivity and learning deficits, but has less of an effect on memory retention.

To better understand the relationship between neurodegeneration of the cholinergic system and neurons in the hippocampus with behavior, linear regression analysis was performed. A significant inverse relationship was found between ChAT immunoreactivity in the hippocampus and total activity (Fig. 7A) and between ChAT immunoreactivity in the hippocampus and the probe test (Fig. $7 B$ ); no correlation was found with total rearing (Fig. 7C). Total activity in the open field was correlated to a lesser extent with neuronal counts in the CA3 (Fig. 7D), but a stronger correlation was found between neurons in $\mathrm{CA} 3$ and the probe test (Fig. 7E); no correlation was found with rearing (Fig. $7 F$ ). Together, these results suggest that hyperactivity might be closely related to ChAT immunoreactivity levels in the hippocampus and memory acquisition in the probe test related with CA3 neurons in the hippocampus.

Deleting endogenous $\alpha$-syn modulates Rabs and neurotrophic factors in APP Tg mice

We showed that reducing endogenous $\alpha$-syn protects the cholinergic system (Fig. 3) and glutamatergic neurons in the hippocam- pus (Fig. 4). Survival of these neuronal populations is dependent on NGF and BDNF transport to the target (Schliebs and Arendt, 2011) and sorting of NGF/BDNF to the target cells is dependent on Rabs, including Rab3a, Rab5, Rab7, and Rab8 (Cui et al., 2007). This suggests that alterations in Rabs in the APP Tg mice could participate in the mechanisms of defective NGF/BDNF transport, which could account for the selective degeneration of cholinergic fibers and hippocampal neurons. We hypothesize that these alterations can be reverted by ablating $\alpha$-syn. In this context, we performed immunoblot analysis and found that, compared with the non-Tg group, the APP Tg mice displayed a decrease in Rab3a and an increase in Rab5 and Rab11 protein levels (Fig. 8A-C,E); however, no differences in the levels of Rab7 protein were observed among the four groups (Fig. $8 A, D$ ). In contrast in the APP Tg/ $\alpha$-syn KO mice, protein levels of Rab3a and Rab5 were normalized (Fig. $8 A-C, E$ ), whereas protein levels of Rab11 remained elevated (Fig. $8 A, E$ ).

Immunocytochemical analysis with antibodies against Rab3a, Rab5, Rab7, and Rab11 displayed a granular pattern of immunostaining in the cytoplasm and neuropil (Fig. $8 F$ ). Compared with non-Tg mice, the APP Tg mice displayed reduced levels of Rab3a (Fig. $8 F, G$ ) and increased Rab5 (Fig. 8F,H) and Rab11 (Fig. $8 F, J)$. No differences in Rab7 were observed among the four groups (Fig. $8 F, I$ ). In contrast, in the APP Tg/ $\alpha$-syn KO mice, levels of Rab3a and Rab5, but not Rab11, were normalized (Fig. $8 F-J)$. To determine whether these changes in Rabs were at a transcriptional level, qPCR was performed for Rab3a. Whereas 

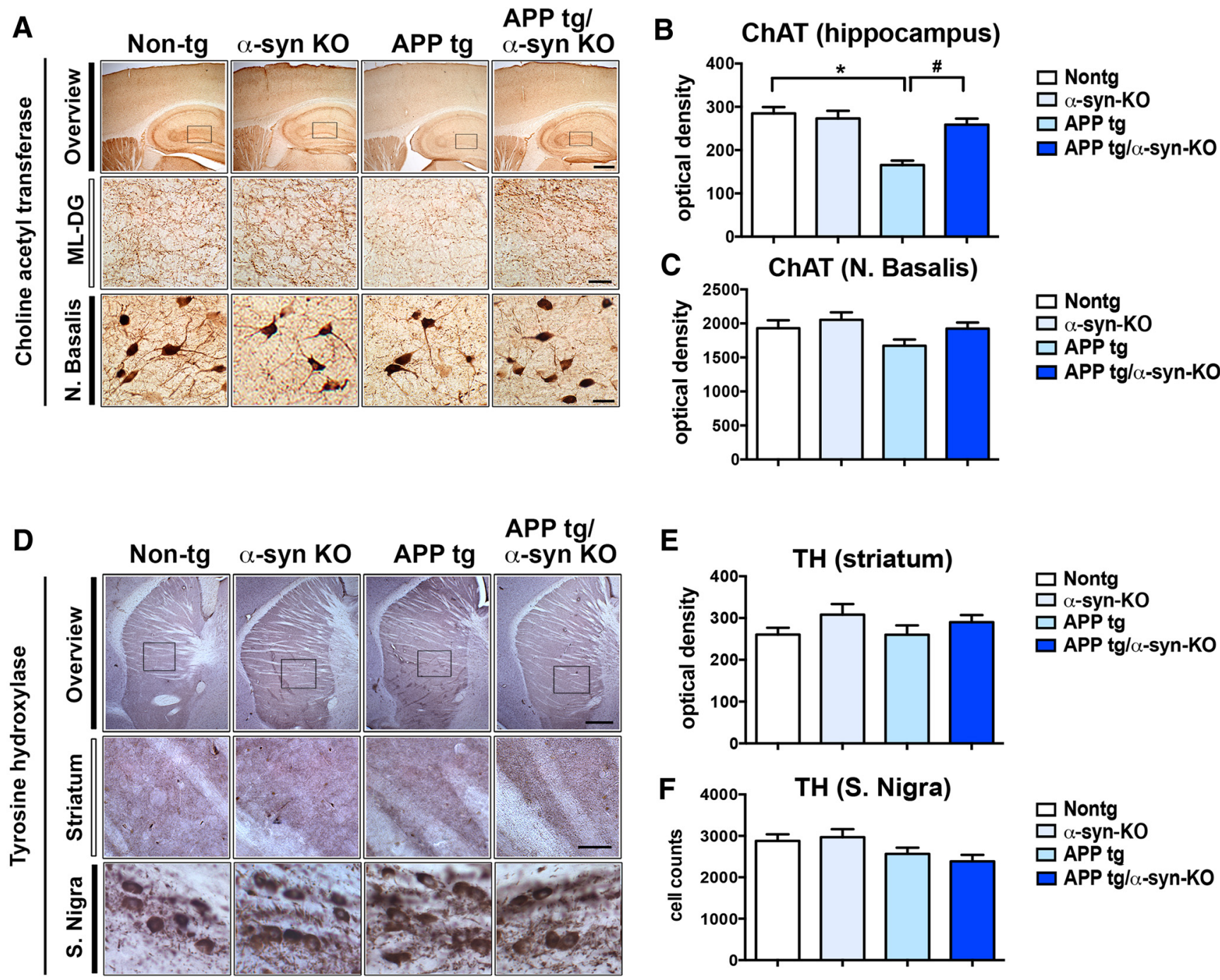

Figure 3. Immunocytochemical analysis of the cholinergic and dopaminergic systems in the APP $\mathrm{Tg}$ and APP $\mathrm{Tg} / \alpha$-syn KO mice. Vibratome sections were immunostained with an antibody against ChAT or TH. $A$, Representative low-magnification photomicrographs of the frontal cortex, CA3, and CA1 regions of the hippocampus and representative high-magnification photomicrographs of the molecular layer of the dentate gyrus and the nucleus basalis from non- $\mathrm{Tg}, \mathrm{APP} \mathrm{Tg}, \alpha$-syn $\mathrm{KO}$, and APP Tg/ $\alpha$-syn K0 mice immunoreacted with anti-ChAT. Endogenous ChAT was observed in a neuritic fiber pattern in the neuropil of the molecular layer of the dentate gyrus of the hippocampus in each mouse line. $\boldsymbol{B}$, Corrected optical densitometry of ChAT immunoreactivity in the molecular layer of the dentate gyrus was significantly decreased in the APP Tg mice compared with non-Tg mice, whereas ChAT-immunoreactive levels were significantly increased in APP $\mathrm{Tg} / \alpha$-syn KO mice compared with APP Tg mice. C, Corrected optical densitometry analysis of ChAT immunoreactivity in the nucleus basalis revealed no significant differences between the mouse lines. $\boldsymbol{D}$, Representative photomicrographs of TH immunoreactivity in the striatum at low and high magnification and the substantia nigra at high magnification. $\boldsymbol{D}, \boldsymbol{E}$, There was no significant difference between mouse lines in the corrected optical density in the striatum $(\boldsymbol{E})$ or cell counts in the substantia nigra $(\boldsymbol{F})$. Statistical analysis was conducted using one-way ANOVA post hoc Dunnett's test for comparison with non-Tg mice $\left(^{*}\right.$ ) and Tukey-Kramer post hoc analysis for comparison with $\alpha$-syn Tg mice (\#). For analysis, 10 mice $4-6$ months of age were used. Scale bars, $200 \mu \mathrm{m}$ in low-power images and $40 \mu \mathrm{m}$ in high-power images.

there was a trend for APP Tg/ $\alpha$ syn KO mice toward increased levels of Rab3a, it did not reach the level of statistical significance (one-way ANOVA with Dunnett's post hoc analysis; $p=0.0953$ ). The fold changes \pm SDs were as follows: non-Tg mice (1.0 \pm $0.40)$, APP Tg mice $(0.91 \pm 0.35 ; 95 \%$ confidence interval $=$ -0.5444 to 0.7240$), \alpha$-syn KO mice $(0.76 \pm 0.49$; $95 \%$ confidence interval $=-0.4654$ to 0.9526 ), and APP Tg/ $\alpha$-syn KO mice $(1.52 \pm 0.49 ; 95 \%$ confidence interval $=-1.230$ to 0.1883$)$. Next, we analyzed the levels of NGF and BDNF in the hippocampus. We have shown previously that, in this APP Tg mouse line, there is decreased maturation of neurotrophic factors (Ubhi et al., 2013). Consistent with these reports, we observed increased levels of pro-NGF and pro-BDNF in the APP mice compared with the non-Tg mice (Fig. $9 A-C$ ), whereas, in the APP Tg $/ \alpha$-syn KO mice, levels of pro-NGF and pro-BDNF were normalized and similar to those in non-Tg mice (Fig. 9A-C). Likewise, compared with the non-Tg mice, levels of mature NGF and BDNF were reduced in the APP mice (Fig. $9 D-F$ ), whereas, in the APP Tg/ $\alpha$ syn $\mathrm{KO}$ mice, levels of mature NGF and BDNF were comparable to those in the non-Tg mice (Fig. $9 D-F$ ).

Rab3a overexpression and $\alpha$-syn knock-down rescues the degeneration of cholinergic neurons exposed to $\mathrm{A} \beta$ $\alpha$-syn plays an important role in regulating vesicle trafficking from the Golgi via interactions with Rab3a and Rab8 (Cooper et al., 2006). To further investigate the involvement of Rab3a in mediating the neuroprotective effects in the $\alpha$-syn knock-down background, a cholinergic cell line N2A was exposed to A $\beta$ oligomers in the presence or absence of LV shRNA targeting $\alpha$-syn or LV overexpressing Rab3a. Under baseline conditions, the N2A 

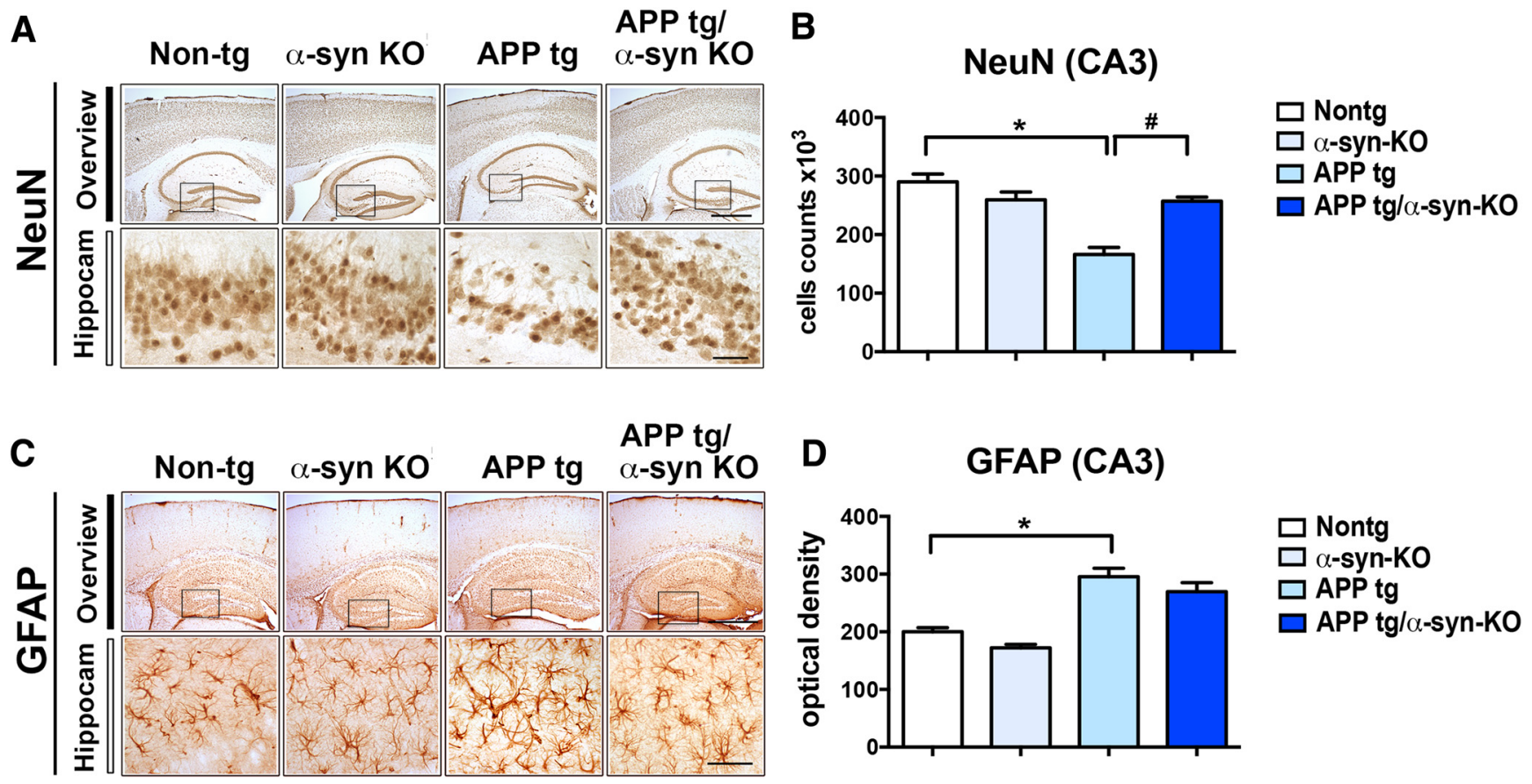

Figure 4. Immunocytochemical analysis of neuronal loss in the hippocampus of APP $\mathrm{Tg}$ and APP $\mathrm{Tg} / \alpha$-syn K0 mice. A, Representative low-and high-magnification photomicrographs of the hippocampal CA3 region of vibratome-cut sections immunoreacted with an antibody against NeuN. $\boldsymbol{B}$, Stereological assessment of every $12^{\text {th }}$ section revealed a significant decrease in the number of neurons in the CA3 in APP Tg mice compared with non- $\mathrm{Tg}$ mice. APP $\mathrm{Tg} / \alpha$-syn $\mathrm{KO}$ mice had a significant increase in the number of neurons in the CA3, which was statistically indistinguishable from non-Tg mice. C, Representative low- and high-magnification photomicrographs of the hippocampal CA3 region using vibratome-cut sections immunoreacted with an antibody against GFAP. D, Optical density assessment of GFAP immunoreactivity in the CA3 of the hippocampus indicated a statistically significant increase for APP Tg and APP Tg/ $\alpha$-syn KO mice compared with non-Tg mice. Statistical analysis was conducted using one-way ANOVA post hoc Dunnett's test for comparison with non-Tg mice $\left({ }^{*} p<\right.$ 0.05 ) and Tukey-Kramer for comparison with APP Tg mice (\#p < 0.05). For analysis, 10 mice 4-6 months of age were used from each mouse type. Scale bars, $200 \mu \mathrm{m}$ in low-power images and $40 \mu \mathrm{m}$ in high-power images.

A

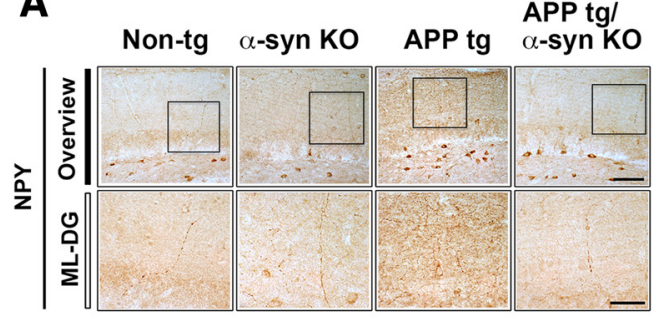

D

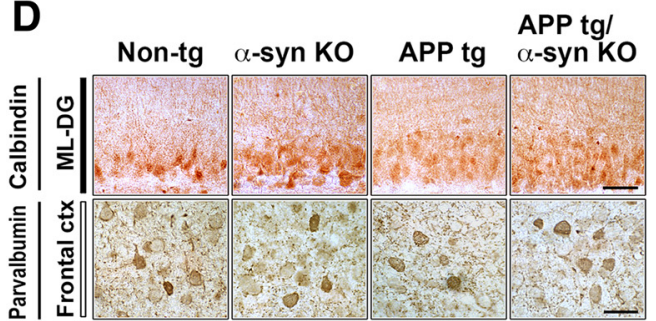

B

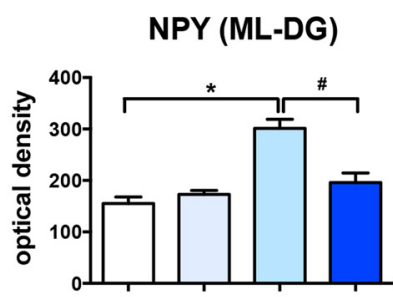

$E$
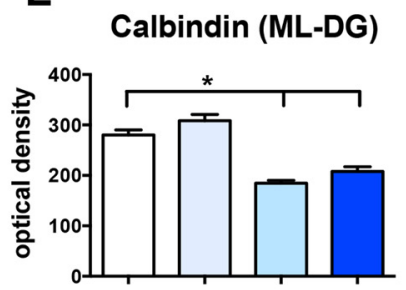

C

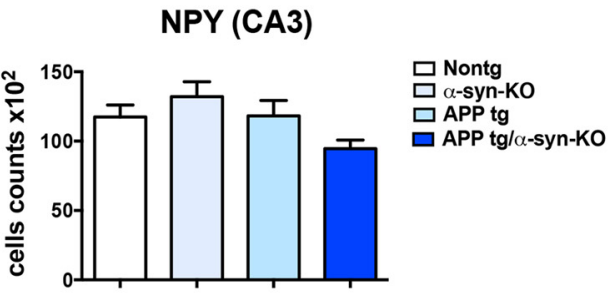

$F$

Parvalbumin (ML-DG)

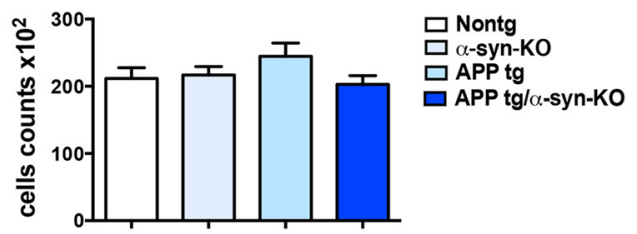

Figure 5. Immunocytochemical analysis of NPY-, calbindin-, and parvalbumin-positive neurons in APP $\mathrm{Tg}$ and APP Tg/ $\alpha$-syn K0 mice. A, NPY immunocytochemical analysis was performed in the molecular layer of the dentate gyrus and CA3 region of the hippocampus. Representative low- and high-magnification photomicrographs of NPY immunoreactivity in the hippocampus are shown. $\boldsymbol{B}$, In the molecular layer of the dentate gyrus, NPY-immunoreactive fibers were significantly increased in APP Tg mice compared with non-Tg mice and significantly decreased in APP Tg/ $\alpha$-syn K0 mice compared with APP Tg mice. C, Number of NPY-immunoreactive cells in the CA3 region of the hippocampus was unaffected by genotype. $\boldsymbol{D}$, Representative photomicrographs of calbindin- and parvalbumin immunoreactivity in the molecular layer of the hippocampus. $\boldsymbol{E}$, Optical density analysis of calbindin immunoreactivity revealed significant decreases in both APP $\mathrm{Tg}$ and APP $\mathrm{Tg} / \alpha$-syn $\mathrm{KO}$ mice compared with non-Tg mice. $\boldsymbol{F}$, Number of parvalbumin-immunopositive cells was unaffected by mouse line. Statistical analysis was conducted using one-way ANOVA post hoc Dunnett's test for comparison with non-Tg mice ${ }^{*} p<0.05$ ) and Tukey-Kramer test for comparison with APP Tg mice (\#p < 0.05). For analysis, 10 mice 4-6 months of age were used from each mouse type. Scale bars, $200 \mu \mathrm{m}$ in low-power images and $40 \mu \mathrm{m}$ in high-power images. 

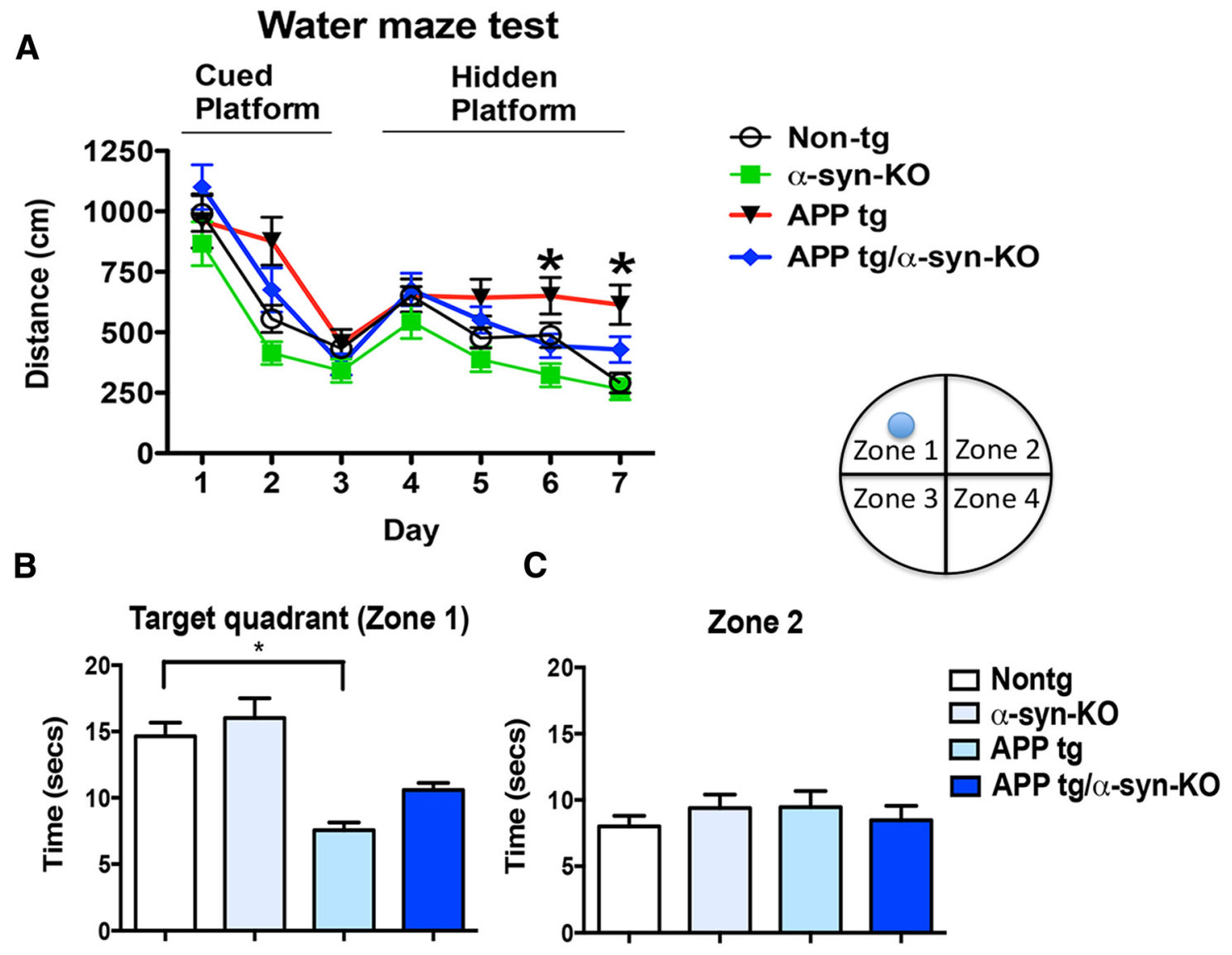

D

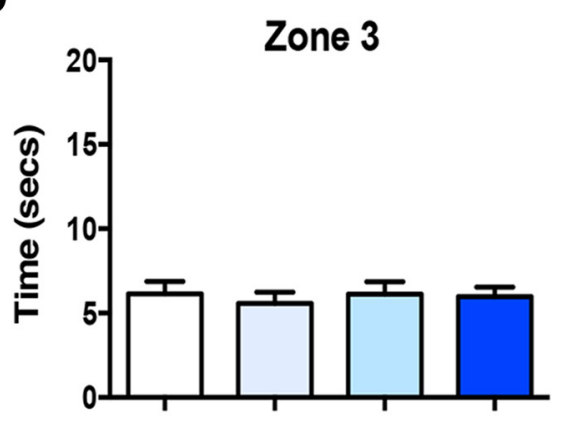

E
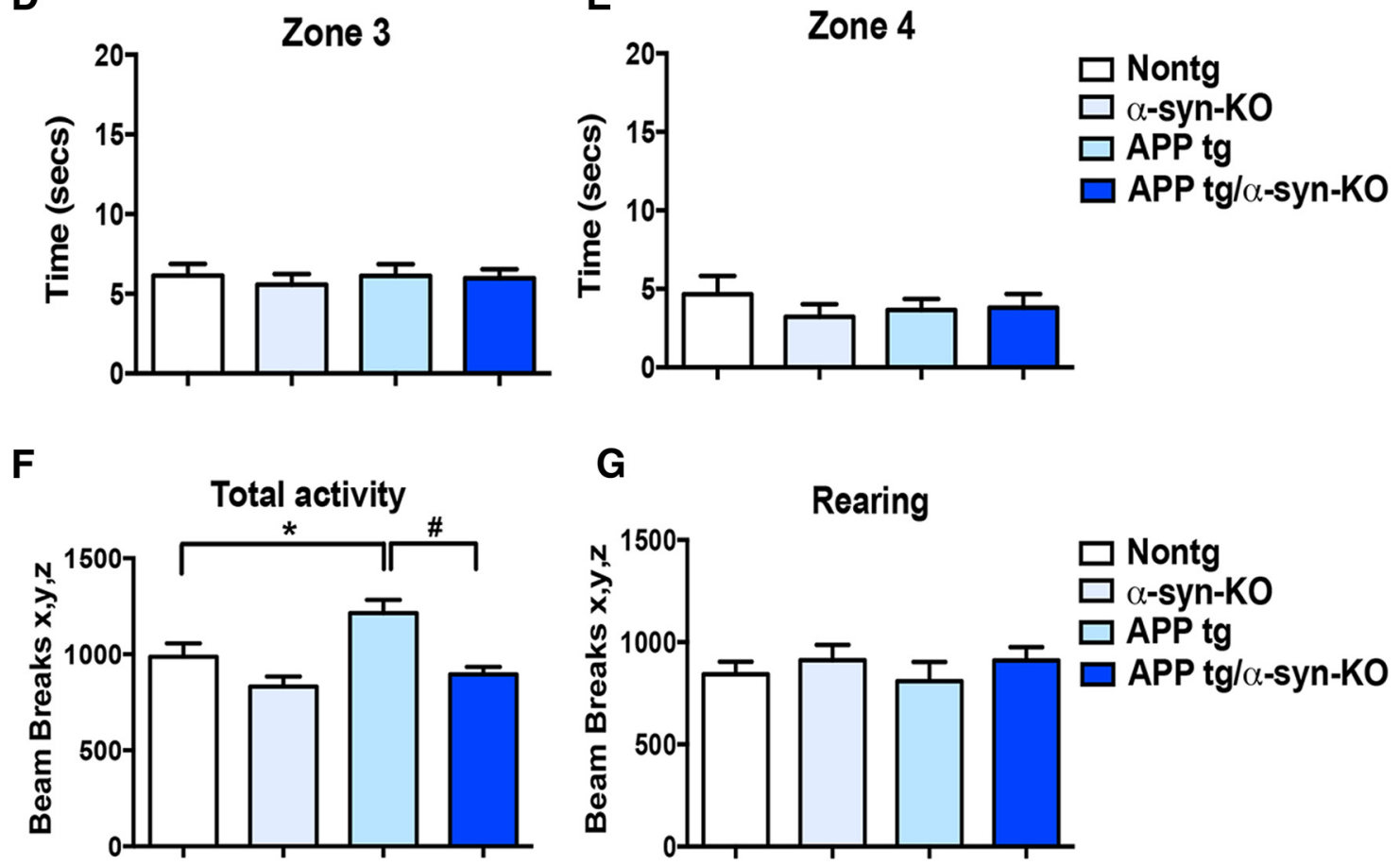

Figure 6. Morris water maze and open-field behavioral analysis in APP Tg and APP Tg/ $\alpha$-syn K0 mice. $A$, Morris water maze test was performed in two phases. The first phase was the training portion conducted on days 1-3 and the second phase was with the platform hidden on days 4-7. During the hidden platform test, the APP Tg mice performed significantly worse in spatial learning portion of the test for comparison with non-Tg mice; however, the APP Tg/ $\alpha$-syn K0 mice were similar to non-Tg mice. B, Probe test (day 8) was performed without the platform and the amount of time spent in the quadrant that used to contain the platform was analyzed. APP Tg and APP Tg/ $\alpha$-syn KO mice spent significantly less time in the target quadrant compared with non-Tg and $\alpha$-syn KO mice. $\boldsymbol{C}-\boldsymbol{E}$, Time spent in nontarget quadrants. $\boldsymbol{F}$, Open field behavioral test indicated a statistically significant increase in total activity (hyperactivity) for APP Tg mice compared with non-Tg mice, but APP Tg/ $\alpha$-syn K0 mice were statistically decreased compared with APP Tg mice. G, Rearing was unaffected by mouse genotype. Statistical analysis was conducted using one-way ANOVA post hoc Dunnett's test for comparison with non-Tg mice ${ }^{*} p<$ 0.05 ) and Tukey-Kramer test for comparison with APP Tg mice (\#p < 0.05). For analysis, 10 mice $4-6$ months of age were used from each mouse type. 
A

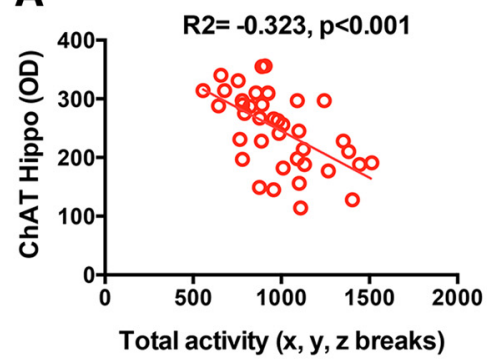

D

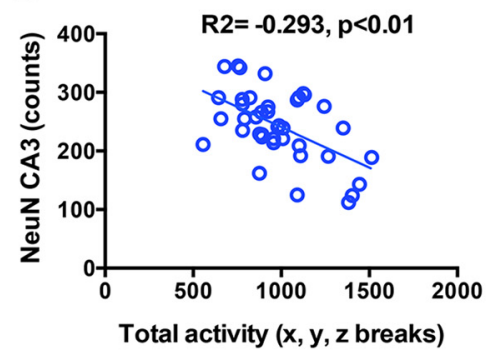

B

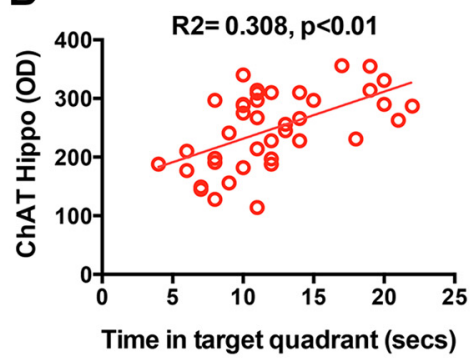

E

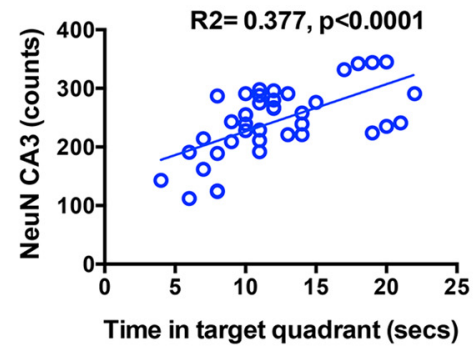

C

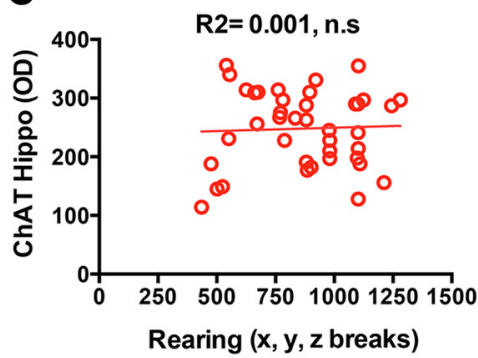

$F$

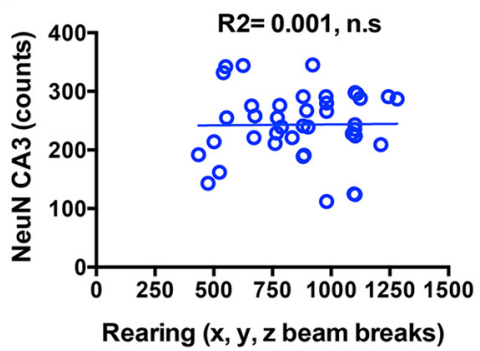

Figure 7. Linear regression analysis between markers of neurodegeneration and behavior. $\boldsymbol{A}$, Correlation between ChAT immunoreactivity in the hippocampus and total activity. $\boldsymbol{B}$, Correlation between ChAT immunoreactivity in the hippocampus and the probe test. $C$, Correlation between total rearing and ChAT immunoreactivity in the hippocampus. $\boldsymbol{D}$, Correlation between neurons in the CA3 and total activity. $\boldsymbol{E}$, Correlation between CA3 hippocampal neurons and the probe test. $\boldsymbol{F}$, No correlation was found between total rearing and CA3 hippocampal neurons. For analysis, 10 mice 4-6 months of age were used from each mouse type.

cells expressed $\alpha$-syn (Fig. 10A,B), ChAT (Fig. 10A,C), Rab3a (Fig. 10A,D), and Rab5 (Fig. $10 A, E$ ). After challenge with $\mathrm{A} \beta$ alone, levels of $\alpha$-syn immunostaining (Fig. 10A,B) and Rab5 were increased (Fig. 10A,E), whereas levels of ChAT (Fig. 10A,C) and Rab3a (Fig. 10A,D) were decreased. Reducing levels of $\alpha$-syn with a LV-shRNA or enhanced expression of Rab3a with a LV protected N2A cells from the toxic effects of exogenous $A \beta$ oligomers and rescued the expression levels of ChAT, Rab3a, and Rab5 (Fig. 10A-E).

Next, after exposure of $\mathrm{N} 2 \mathrm{~A}$ cells to $\mathrm{A} \beta$ oligomers in the presence or absence of LV shRNA targeting $\alpha$-syn or LV overexpression of Rab3a, we double immunolabeled the N2A cells with antibodies against NGF and neurotubulin to analyze the distribution of neurotrophic factors along the neuronal cell body and neuritic processes (Fig. 11). Under baseline conditions, most of the NGF was localized to the neuronal cell processes (Fig. 11A, B). After $\mathrm{A} \beta$ challenge, NGF redistributed from the neurites to the neuronal cell body (Fig. $11 A, B$ ). When N2A cells were infected with the LV-shRNA $\alpha$-syn or LV-Rab3a and treated with A $\beta$ oligomers, NGF localized both to the neuritic processes and neuronal cell body (Fig. 11A,B). Together, these studies suggest that $\mathrm{A} \beta$ oligomers might lead to degeneration of cholinergic cells by interfering with Rab3a via $\alpha$-syn, which in turn might result in alterations in the intracellular trafficking of neurotrophic factors.

\section{Discussion}

The present study showed that deleting endogenous $\alpha$-syn prevented the degeneration of hippocampal CA3 neurons and the cholinergic terminals in the hippocampus of APP Tg mice. This was accompanied by improvements in behavioral performance and recovery in levels of Rab3a and Rab5 proteins involved in intracellular transport and sorting of NGF and BDNF. Likewise, in vitro overexpression of Rab3a or $\alpha$-syn knock-down with shRNA protected cholinergic neurons from the toxic effects of $\mathrm{A} \beta$ oligomers. Together, these results suggest that $\alpha$-syn might participate in mechanisms of vulnerability of selected neuro- nal populations in $\mathrm{AD}$ and that reducing $\alpha$-syn might be a potential approach to protecting these populations from the toxic effects of $\mathrm{A} \beta$.

In agreement with the finding that $\alpha$-syn ablation might be neuroprotective, previous studies have shown that knocking down $\alpha$-syn protects experimental models from the toxic effects of MPTP (Drolet et al., 2004; Javed et al., 2015), 3-nitropropionic acid (Ubhi et al., 2010), and spinal cord injury (Wang et al., 2016). The mechanisms through which reducing $\alpha$-syn might protect neuronal populations from selected injuries or toxins such as $\mathrm{A} \beta$ oligomers are not completely understood. However, given that $\alpha$-syn has been proposed to play a role in intracellular vesicular trafficking (Cooper et al., 2006), one possibility is that reducing $\alpha$-syn might attenuate the $\mathrm{A} \beta$-triggered alterations in vesicular trafficking. In $\mathrm{AD}$, previous studies have shown abnormal endocytic function with enlarged Rab5 endosomes and alterations in Rab7 that might result in defective neurotrophic factor (NTF) transport (Almeida et al., 2006; Wu et al., 2009; Ginsberg et al., 2010; Li et al., 2012; Wang et al., 2014). It has been shown that Rab1B and 6 are involved in the transport and processing of APP, and Rab6 and Rab11 facilitate BACE1 and PS1 trafficking (Wang et al., 2014). Moreover, previous studies have shown that, of several synaptic and vesicular transport proteins investigated, Rab3a and the postsynaptic protein synaptopodin were the most downregulated (Reddy et al., 2005). In agreement with these studies, we found that, in APP Tg mice, protein levels of Rab3a were reduced, whereas levels of Rab5 and Rab11 were elevated. Remarkably, ablation of $\alpha$-syn in the APP Tg mice reversed the alterations in Rab3a, Rab5, and Rab11, but had no effect on Rab7. Likewise, $\alpha$-syn knock-down or Rab3a overexpression protected cholinergic neuronal cells from the toxic effects of $A \beta$ oligomers. This might be relevant to explaining mechanisms of selective vulnerability because Rabs are involved in the transport of the TrkA/B, NGF, and BDNF. More than 60 members of the Rab family have been identified in mammals, with 11 homologs in 
A

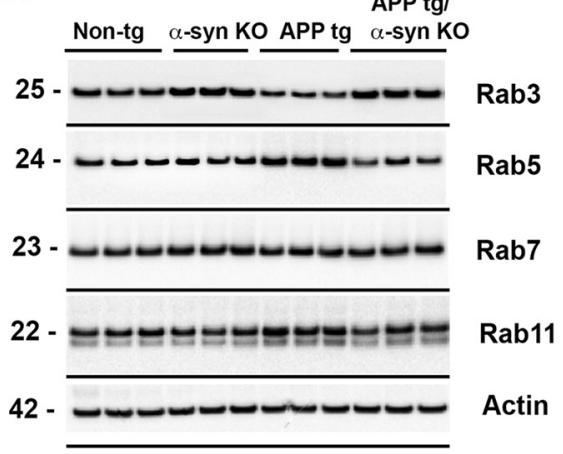

F
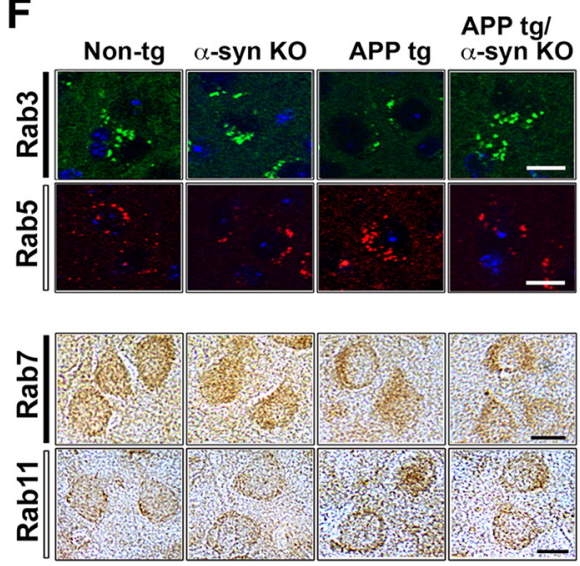

B

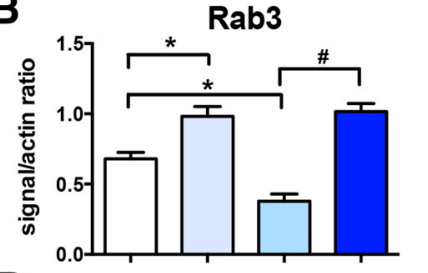

D

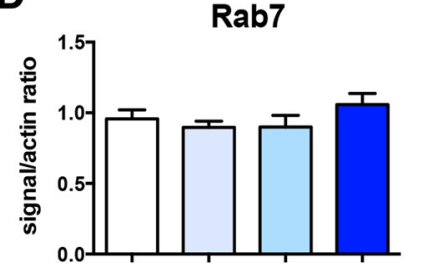

G

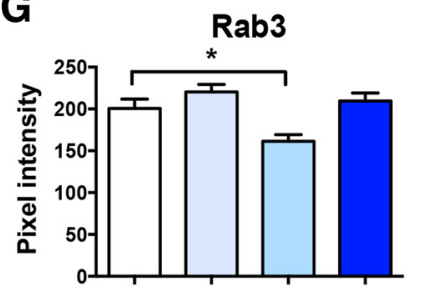

Rab7

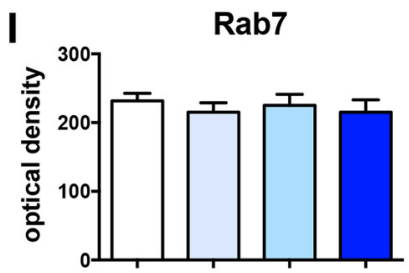

C

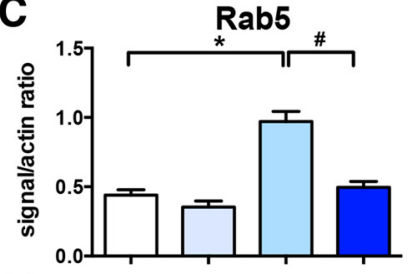

E
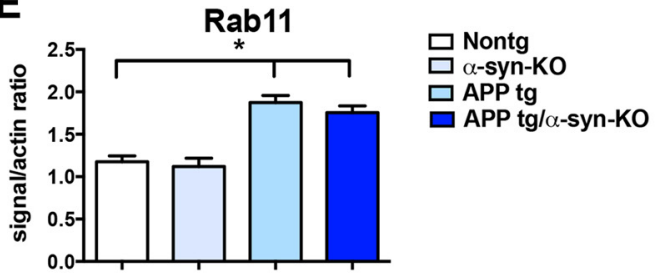

H

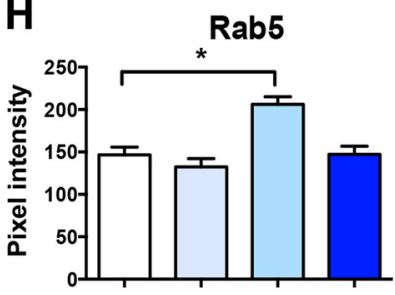

$\square$ Nontg

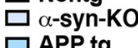

$\square$ APP tg

$\square$ APP tg/ $\alpha-s y n-K O$

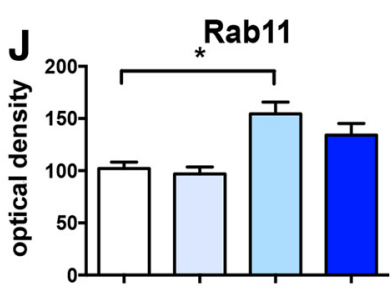

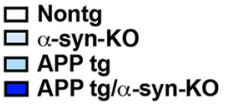

$\square$ APP tg/ $\alpha$-syn-KO

$\square$ APP tg/ $\alpha-s y n-K O$

Figure 8. Western blot and immunocytochemical analysis of Rab expression pattern in APP $\mathrm{Tg}$ and APP $\mathrm{Tg} / \alpha$-syn $\mathrm{KO}$ mice. $A$, Western blots were performed using with the membrane fractions obtained from the hippocampus and cortex lysate and probed with antibodies against Rab $3(25 \mathrm{kDa}), 5(24 \mathrm{kDa}), 7$ (23 kDa), and 11 (double band $\sim 22 \mathrm{kDa}$ ). B, Computer-aided analysis of Rab3a indicated a significant increase in $\alpha$-syn K0 and APP Tg/ $\alpha$-syn $\mathrm{KO}$ mice compared with non-Tg mice. In contrast, APP Tg mice displayed a significant reduction compared with non-Tg mice. Protein levels in APP Tg/ $\alpha$-syn KO mice were significantly increased compared with $\alpha$-syn K0 mice and statistically equivalent to non-Tg mice. C, Rab5 protein levels were significantly increased in APP Tg mice compared with non-Tg mice. $\alpha$-syn ablation resulted in comparable levels of Rab5 in APP Tg/ $\alpha$-syn K0 and $\alpha$-syn K0 mice. D, Rab7 protein levels were unchanged across mouse type. $\boldsymbol{E}$, Rab11 protein levels were significantly increased in APP Tg and APP Tg/ $\alpha$-syn K0 mice compared with non-Tg mice. $F$, Confocal image analysis of Rab3a and Rab5 and photomicrograph analysis of Rab7 and Rab11 expression in the hippocampus. G, Computer-aided image analysis indicated APP Tg mice had significantly decreased Rab3a immunoreactivity compared with non-Tg mice. APP Tg/ $\alpha$-syn KO mice Rab3a immunoreactivity was significantly increased compared with APP Tg mice and statistically equivalent to non-Tg mice. $\boldsymbol{H}$, Computer-aided image analysis indicated that APP Tg mice had significantly increased Rab5 immunoreactivity compared with non-Tg mice. APP Tg/ $\alpha$-syn K0 mice Rab5 immunoreactivity was significantly decreased compared with APP Tg mice and statistically equivalent to non-Tg mice. I, Computer-aided image analysis of Rab7 indicated no difference between mouse types. J, Computer-aided image analysis of Rab 11 immunoreactivity indicated a statistically significant increase in APP Tg mice compared with non- $\mathrm{Tg}$ mice. APP Tg/ $\alpha$-syn K0 mice were statistically equivalent to non-Tg mice. Statistical analysis was conducted using one-way ANOVA post hoc Dunnett's test for comparison with non-Tg mice $\left({ }^{*} p<0.05\right)$ and Tukey-Kramer test for comparison with APP Tg mice (\#p $\left.<0.05\right)$. For analysis, 10 mice $4-6$ months of age were used from each mouse type. Scale bar, $10 \mu \mathrm{m}$.

yeast (Cosker and Segal, 2014). For example, Rab5 and Rab7 are, respectively, associated with the early and late endosomes involved in regulating the trafficking of NTFs and receptorcontaining vesicles to the perinuclear region for cell survival signals such as ERK, Akt, and CREB (Bucci et al., 2014), whereas the secretory pathways use Rab11, among others, when involving exosomes and Rab3a and Rab8 when involving the Golgi apparatus (Huotari and Helenius, 2011; Colombo et al., 2014).

Yeast and murine studies have shown that $\alpha$-syn has a role in regulating vesicle trafficking from the Golgi via interactions with Rab3a and Rab8 (Cooper et al., 2006). In contrast, previous studies in DLB and $\alpha$-syn Tg models have shown that $\alpha$-syn aggregates disrupt endocytic and secretory pathways via abnormal interactions with Rab3A, Rab5, and Rab8 (Eisbach and Outeiro, 2013; Wang et al., 2014). These alterations can be reversed by overexpression of Rab1, Rab3a, and Rab11. Furthermore, exogenously added $\alpha$-syn protofibrils interact with Rabs and interfere with axonal transport and signaling of TrkB (Volpicelli-Daley et al., 2014). Finally, mutations in Rab7L1 and VPS35 have been associated with familial forms of parkinsonism (MacLeod et al., 2013; Perrett et al., 2015) and, whereas the mechanisms are not completely clear, a number of recent studies have indicated that Rab7L1 and VPS35 mutations might lead to deficient intracellular $\alpha$-syn transport and clearance, resulting in accumulation of $\alpha$-syn toxic species (Dhungel et al., 2015). In contrast, overexpression of wild-type VPS35 and Rab7L1 rescued the phenotypes induced by $\alpha$-syn and LRRK2 mutations, respectively (MacLeod et al., 2013; Perrett et al., 2015). Together, these studies support the possibility that, among other $\alpha$-syn-affected mechanisms, A $\beta$ might disrupt intracellular trafficking, which is important for the transport and signaling of NTFs relevant to neuronal populations in the hippocampus and nucleus basalis.

APP Tg/ $\alpha$-syn KO mice showed selective protection against the loss of hippocampal and cholinergic neurons, which may be partially attributed to the levels of mGluR5. Subpopulations of hippocampal (Overk et al., 2014) and cholinergic (Wu et al., 

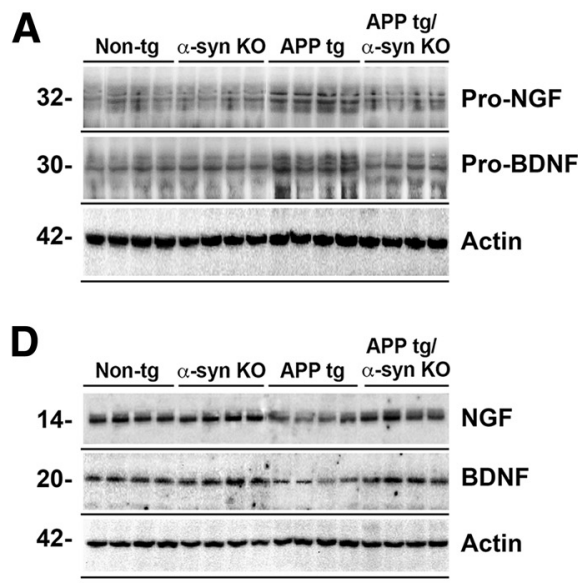

B

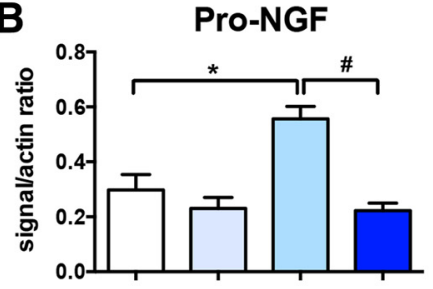

$\mathbf{E}$

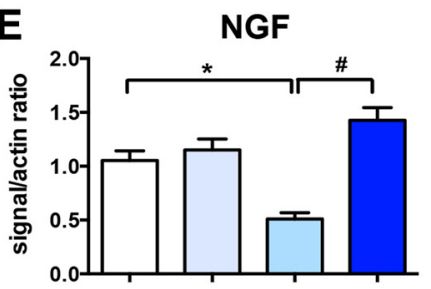

C

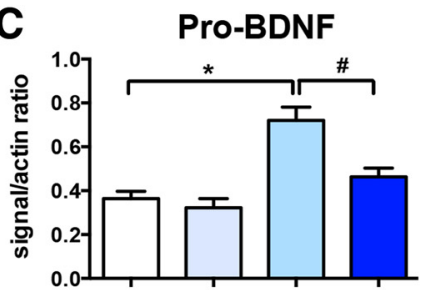

F

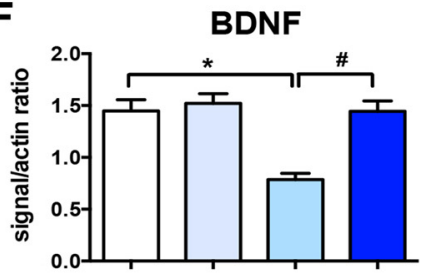

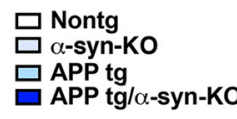

Figure 9. Western blot analysis of pro-NGF, pro-BDNF, NGF, and BDNF. Brain lysates from the cortex and hippocampus were fractionated and the membrane fraction was used for immunoblot analysis. $\boldsymbol{A}$, Representative Western blot of pro-NGF ( $\sim 32 \mathrm{kDa}$, double band) and pro-BDNF ( $\sim 30 \mathrm{kDa}$, single band). $\boldsymbol{B}, \boldsymbol{C}$, Computer-aided analysis of immunoblot of Pro-NGF $(\boldsymbol{B})$ and Pro-BDNF signals normalized to actin signal (C) showing accumulation of the precursor growth factors in the APP Tg mice but normalization in the APP Tg/ $\alpha$-syn-KO mice. $\boldsymbol{D}$, Representative Western blot of $\operatorname{NGF}(\sim 14 \mathrm{kDa}$, double band) and BDNF ( $\sim 20 \mathrm{kDa}$, single band). $\boldsymbol{E}$, $\boldsymbol{F}$, Densitometry analysis of immunoblot of NGF $(\boldsymbol{E})$ and BDNF signals normalized to actin $(\boldsymbol{F})$ showing decreased growth factors in the APP Tg mice but normalization of the signal in the APP Tg/ $\alpha$-syn-KO mice. Statistical analysis was conducted using one-way ANOVA post hoc Dunnett's test for comparison with non-Tg mice $\left({ }^{*} p<0.05\right)$ and Tukey-Kramer test for comparison with APP Tg mice (\#p <0.05). For analysis, 10 mice $4-6$ months of age were used from each mouse type.

A
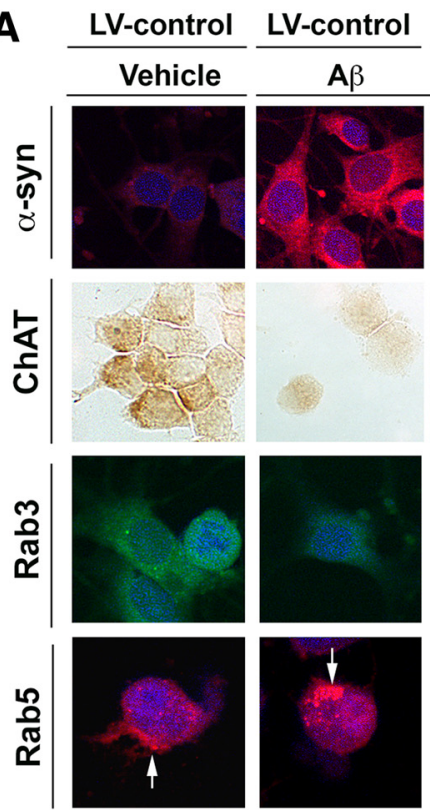

LV-sh- $\alpha-s y n$ A $\beta$
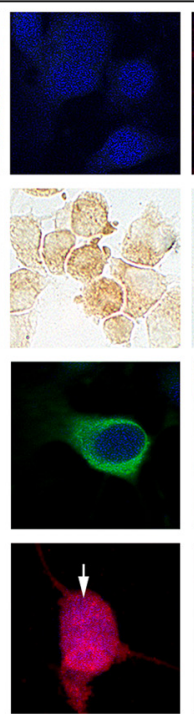

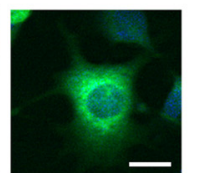

LV-Rab3
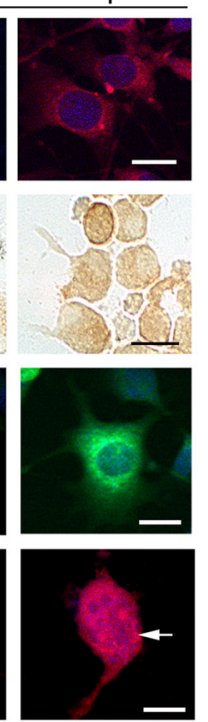

B

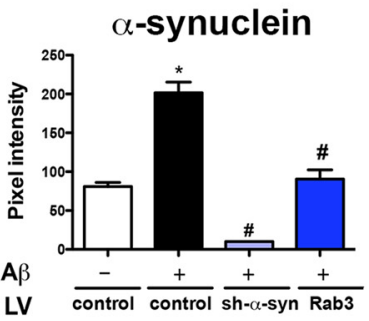

D

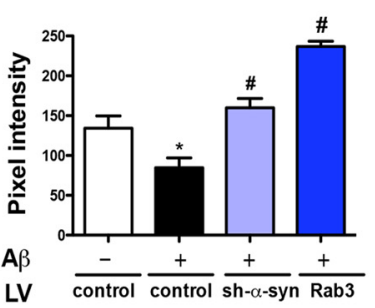

C

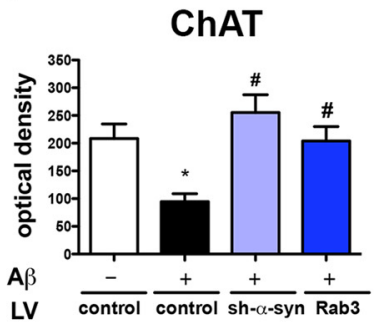

$\mathbf{E}$

Rab5

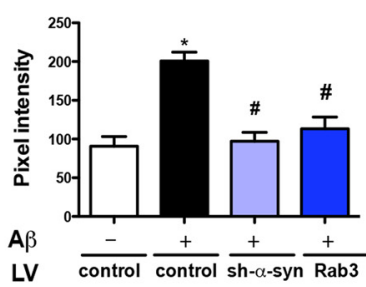

Figure 10. Effects of LV-sh- $\alpha$-syn and LV-Rab3a over expression on $\alpha$-syn, ChAT, Rabs 3a and 5 immunoreactivity in the in vitro neuronal cholinergic cell line, N2A. Differentiated N2A neuronal cells were exposed to $\mathrm{A} \beta$ oligomer ( $5 \mathrm{~nm}$ ) or vehicle for $24 \mathrm{~h}$ in the presence or absence of $\alpha$-syn shRNA (knock-down $\alpha$-syn) or LV-overexpressing Rab3a. $A$, Cells were immunoreacted with antibodies against $\alpha$-syn (red), ChAT (DAB), Rab3a (green), or Rab5 (red). B, Coverslips were analyzed to determine levels of $\alpha$-syn immunoreactivity expressed as pixel intensity. Computer-aided image analysis of $\alpha$-syn-immunopositive pixel intensity indicated a low baseline expression of $\alpha$-syn, which was significantly increased in N2A cells exposed to A $\beta$ oligomers. Compared with N2A cells treated with A $\beta$ oligomers, LV-sh- $\alpha$-syn and LV-Rab3 both significantly reduced $\alpha$-syn immunoreactivity. C, Coverslips were analyzed to by optical density to determine levels of ChAT. Computer-aided analysis of optical density revealed that ChAT immunoreactivity was significantly decreased in N2A cells exposed to A $\beta$ oligomers. Both LV-sh- $\alpha$-syn and LV-Rab3 showed significantly increased ChAT immunoreactivity in the presence of $A \beta$ oligomers compared with $A \beta$-treated N2A cells. $D$, Coverslips were analyzed to determine levels of Rab3a immunoreactivity expressed as pixel intensity. Computer-aided analysis of Rab3a pixel intensity indicated that N2A cells exposed to A $\beta$ oligomers was significantly reduced compared with vehicle-treated N2A cells. Both LV-sh- $\alpha$-syn and LV-Rab3 significantly increased the Rab3a pixel intensity in N2A cells exposed to A $\beta$ compared with A $\beta$-treated N2A cells alone. $E$, Computer-aided analysis of Rab5 pixel intensity showed that N2A cells exposed to A $\beta$ oligomer had a significant increase in pixel intensity compared with vehicle-treated N2A cells. Both LV-sh- $\alpha$-syn and LV-Rab3 reduced Rab 5 immunoreactivity in A $\beta$-treated N2A cells to vehicle-treated levels. Statistical analysis was conducted using one-way ANOVA post hoc Dunnett's test for comparison with vehicle-treated N2A control cells ( ${ }^{*} p<0.05$ ) and Tukey-Kramer test for comparison with A $\beta$ oligomer-treated N2A cells ( $\# p<0.05$ ). For analysis, $n=3$.

2004) neurons are mGluR5 positive. We have shown in the present study that the number of neurons in the CA3 pyramidal layer was significantly decreased in APP Tg mice, as well as in $\alpha$-syn Tg and $\alpha$-syn/APP double Tg mice (Overk et al., 2014), most likely due to the presence of mGluR5. Eliminating $\alpha$-syn ( $\alpha$-syn KO mice) or silencing mGluR5 in the CA3 region of the hippocampus (Overk et al., 2014) was neuroprotective, indicating that the neuronal vulnerability associated with $\alpha$-syn- and/or APPrelated neurodegeneration may be at least partially attributed to mGluR5 levels in these brain regions. The mechanism might in- 
A
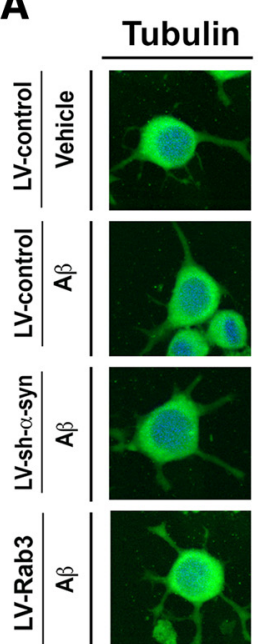
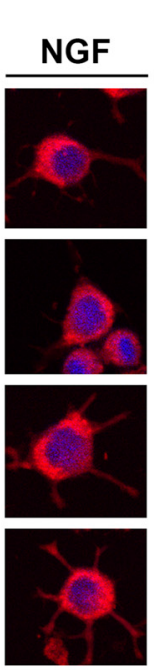
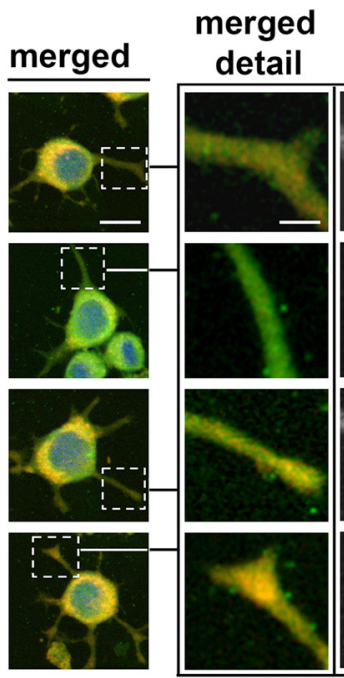

NGF detail

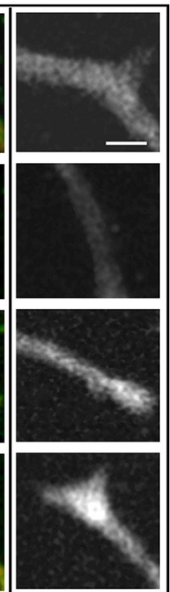

B

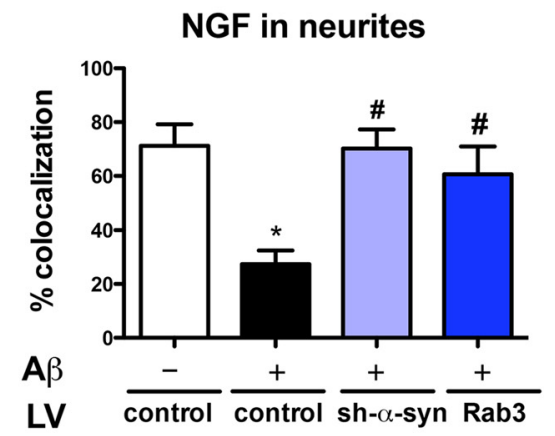

Figure 11. Double labeling and confocal analysis of the effects of LV-sh- $\alpha$-syn and LV-Rab3a overexpression in the localization of NGF in N2A cells treated with A $\beta$. Differentiated N2A neuronal cells were exposed to either vehicle treatment or exposed to $A \beta$ oligomer $(5 \mathrm{~nm})$ for $24 \mathrm{~h}$ and then infected with LV-sh- $\alpha$-syn or LV-Rab3a grown on coverslips were double labeled with antibodies against tubulin and NGF. A, Laser scanning confocal microscopy of N2A cells immunoreacted with antibodies against tubulin (green) or NGF (red), as well as nuclei (DAPI, blue), to show NGF-positive processes. Inset box in merged panel is magnified in both the merged and NGF detailed panels. $\boldsymbol{B}$, Computer-aided image analysis of the percentage of neuritis displaying NGF colocalization with tubulin. This study showed that N2A cells treated with A $\beta$ oligomers had a significant decrease in NGF immunoreactivity in the neuritis. This effect was reversed by either LV-sh- $\alpha$-syn or LV-Rab3a treatment. Statistical analysis was conducted using one-way ANOVA posthoc Dunnett's test for comparison with vehicle-treated N2A control cells ( ${ }^{*} p<0.05$ ) and Tukey-Kramer test for comparison with $A \beta$ oligomer-treated N2A cells (\#p $<0.05$ ). For analysis, $n=3$.

volve $\alpha$-syn aggregates reducing the recycling of mGluR5, so higher levels of mGluR5 are present at the surface and make neurons vulnerable to excitotoxicity. Because the loss of calbindin-positive neurons occurred in the absence of $\alpha$-syn ( $\alpha$ syn $\mathrm{KO}$ and APP Tg/ $\alpha$-syn $\mathrm{KO}$ mice), it is possible that the loss of calbindin-positive neurons may be attributed to other factors in addition to the presence of mGluR5. Calbindin neurons might express low levels of mGluR5 and, in our previous studies, we have not observed upregulation of mGluR5 in granular cell neurons. Similarly, in the hippocampal orein-alveus interneurons, only some type IV interneurons expressed both mGluR5 and calbindin (van Hooft et al., 2000). Moreover, neurodegeneration of these populations of hippocampal cells have been associated with alterations in other glutamate receptors such as NMDA (Choi, 1988).

APP Tg mice showed deficits in learning and memory in the Morris water maze similar to results we have described previously (Rockenstein et al., 2005). The spatial learning deficits in the hidden platform portion of the water maze test were ameliorated by the deletion of the $\alpha$-syn gene in the APP Tg/ $\alpha$-syn KO mice. In the second stage of this test, mice were subjected to the same water maze $24 \mathrm{~h}$ after the last testing date for a probe test to determine whether they could remember the quadrant where the platform had been placed. APP Tg mice spent little time in this quadrant, as had been reported previously (Rockenstein et al., 2005); however, surprisingly, the deletion of the $\alpha$-syn gene had no effect on preventing memory deficits in the probe test. This apparent impediment to memory consolidation in the APP Tg/ $\alpha$-syn KO mice could be related to the inability of the $\alpha$-syn ablation to rescue calbindin-positive neurons in the APP Tg mice. In contrast, the rescue by $\alpha$-syn ablation of the spatial learning deficits in the APP Tg mice might be related to the rescue of CA3 neurons and cholinergic fibers in the hippocampus. These neuronal populations are dependent on NGF and BDNF, both of which are involved in learning and memory consolidation (Woolf et al., 2001; Bekinschtein et al., 2013; Bekinschtein et al.,
2014). In fact, the addition of NGF to N2A cholinergic cells has been shown to induce Zif268, Arc, Nur77, and Rheb specifically, all essential immediate early genes for long-term potentiation and learning (Dickey et al., 2004). Therefore, the interaction between $\alpha$-syn and A $\beta$ might interfere with NGF and BDNF and this effect is rescued by $\alpha$-syn ablation.

In support of the notion that interactions between $A \beta$ and $\alpha$-syn might have a role in the pathogenesis of $\mathrm{AD}$, previous studies in $\mathrm{AD}$ and in APP Tg models have shown that $\alpha$-syn interacts with $\mathrm{A} \beta$ (Tsigelny et al., 2008) and accumulates in selected regions of the amygdala (Popescu et al., 2004; Lippa et al., 2007 ) and hippocampus in AD (Swirski et al., 2014). A $\beta$ promotes $\alpha$-syn aggregation and toxicity (Masliah et al., 2001) and they both have synergistic effects leading to synaptic dysfunction (Wang et al., 2015).

In summary, we show that ablation of endogenous $\alpha$-syn prevented hippocampal neurodegeneration, which was accompanied by recovery of Rab3a and Rab5, as well as behavioral performance. Therefore, these findings support the hypothesis that $\alpha$-syn is an important contributor to $\mathrm{AD}$ pathogenesis and that regulating $\alpha$-syn might also be of therapeutic value in $\mathrm{AD}$.

\section{References}

Abeliovich A, Schmitz Y, Fariñas I, Choi-Lundberg D, Ho WH, Castillo PE, Shinsky N, Verdugo JM, Armanini M, Ryan A, Hynes M, Phillips H, Sulzer D, Rosenthal A (2000) Mice lacking alpha-synuclein display functional deficits in the nigrostriatal dopamine system. Neuron 25:239252. CrossRef Medline

Almeida CG, Takahashi RH, Gouras GK (2006) Beta-amyloid accumulation impairs multivesicular body sorting by inhibiting the ubiquitinproteasome system. J Neurosci 26:4277-4288. CrossRef Medline

Alzheimer's Association (2015) 2015 Alzheimer's disease facts and figures. Alzheimers Dement 11:332-384. CrossRef Medline

Bachhuber T, Katzmarski N, McCarter JF, Loreth D, Tahirovic S, Kamp F, Abou-Ajram C, Nuscher B, Serrano-Pozo A, Müller A, Prinz M, Steiner H, Hyman BT, Haass C, Meyer-Luehmann M (2015) Inhibition of amyloid-beta plaque formation by alpha-synuclein. Nat Med 21:802807. CrossRef Medline 
Bekinschtein P, Kent BA, Oomen CA, Clemenson GD, Gage FH, Saksida LM, Bussey TJ (2013) BDNF in the dentate gyrus is required for consolidation of "pattern-separated" memories. Cell Rep 5:759-768. CrossRef Medline

Bekinschtein P, Cammarota M, Medina JH (2014) BDNF and memory processing. Neuropharmacology 76:677-683. CrossRef Medline

Borchelt RD, Xu G, Notterpek L, Lewis J (2014) Proteostasis and secondary proteinopathy in Alzheimer's l. J Alzheimers Dis Parkinsonism 4:3.

Bucci C, Alifano P, Cogli L (2014) The role of rab proteins in neuronal cells and in the trafficking of neurotrophin receptors. Membranes 4:642-677. CrossRef Medline

Choi BK, Kim JY, Cha MY, Mook-Jung I, Shin YK, Lee NK (2015) betaAmyloid and alpha-synuclein cooperate to block SNARE-dependent vesicle fusion. Biochemistry 54:1831-1840. CrossRef Medline

Choi DW (1988) Glutamate neurotoxicity and diseases of the nervous system. Neuron 1:623-634. CrossRef Medline

Clinton LK, Blurton-Jones M, Myczek K, Trojanowski JQ, LaFerla FM (2010) Synergistic Interactions between Abeta, tau, and alpha-synuclein: acceleration of neuropathology and cognitive decline. J Neurosci 30: 7281-7289. CrossRef Medline

Colombo M, Raposo G, Théry C (2014) Biogenesis, secretion, and intercellular interactions of exosomes and other extracellular vesicles. Annu Rev Cell Dev Biol 30:255-289. CrossRef Medline

Colom-Cadena M, Gelpi E, Charif S, Belbin O, Blesa R, Martí MJ, Clarimón J, Lleó A (2013) Confluence of alpha-synuclein, tau, and beta-amyloid pathologies in dementia with Lewy bodies. J Neuropath Exp Neurol 72: 1203-1212. CrossRef Medline

Cooper AA, Gitler AD, Cashikar A, Haynes CM, Hill KJ, Bhullar B, Liu K, Xu K, Strathearn KE, Liu F, Cao S, Caldwell KA, Caldwell GA, Marsischky G, Kolodner RD, Labaer J, Rochet JC, Bonini NM, Lindquist S (2006) Alpha-synuclein blocks ER-Golgi traffic and Rab1 rescues neuron loss in Parkinson's models. Science 313:324-328. CrossRef Medline

Cosker KE, Segal RA (2014) Neuronal signaling through endocytosis. Cold Spring Harb Perspect Biol 6: pii: a020669. CrossRef Medline

Cui B, Wu C, Chen L, Ramirez A, Bearer EL, Li WP, Mobley WC, Chu S (2007) One at a time, live tracking of NGF axonal transport using quantum dots. Proc Natl Acad Sci U S A 104:13666-13671. CrossRef Medline

Dhungel N, Eleuteri S, Li LB, Kramer NJ, Chartron JW, Spencer B, Kosberg K, Fields JA, Stafa K, Adame A, Lashuel H, Frydman J, Shen K, Masliah E, Gitler AD (2015) Parkinson's disease genes VPS35 and EIF4G1 interact genetically and converge on alpha-synuclein. Neuron 85:76-87. CrossRef Medline

Dickey CA, De Mesquita DD, Morgan D, Pennypacker KR (2004) Induction of memory-associated immediate early genes by nerve growth factor in rat primary cortical neurons and differentiated mouse Neuro2A cells. Neuroscience letters 366:10-14. CrossRef Medline

Drolet RE, Behrouz B, Lookingland KJ, Goudreau JL (2004) Mice lacking alpha-synuclein have an attenuated loss of striatal dopamine following prolonged chronic MPTP administration. Neurotoxicology 25:761-769. CrossRef Medline

Eisbach SE, Outeiro TF (2013) Alpha-synuclein and intracellular trafficking: impact on the spreading of Parkinson's disease pathology. J Mol Med 91:693-703. CrossRef Medline

Esposito A, Dohm CP, Kermer P, Bähr M, Wouters FS (2007) alphasynuclein and its disease-related mutants interact differentially with the microtubule protein tau and associate with the actin cytoskeleton. Neurobiol Dis 26:521-531. CrossRef Medline

Games D, Seubert P, Rockenstein E, Patrick C, Trejo M, Ubhi K, Ettle B, Ghassemiam M, Barbour R, Schenk D, Nuber S, Masliah E (2013) Axonopathy in an alpha-synuclein transgenic model of Lewy body disease is associated with extensive accumulation of C-terminal-truncated alphasynuclein. Am J Pathol 182:940-953. CrossRef Medline

Giasson BI, Forman MS, Higuchi M, Golbe LI, Graves CL, Kotzbauer PT, Trojanowski JQ, Lee VM (2003) Initiation and synergistic fibrillization of tau and alpha-synuclein. Science 300:636-640. CrossRef Medline

Ginsberg SD, Mufson EJ, Counts SE, Wuu J, Alldred MJ, Nixon RA, Che S (2010) Regional selectivity of rab5 and rab7 protein upregulation in mild cognitive impairment and Alzheimer's disease. J Alzheimers Dis 22:631639. CrossRef Medline

Hansen L, Salmon D, Galasko D, Masliah E, Katzman R, DeTeresa R, Thal L, Pay MM, Hofstetter R, Klauber M (1990) The Lewy body variant of
Alzheimer's disease: a clinical and pathologic entity. Neurology 40:1-8. Medline

Havas D, Hutter-Paier B, Ubhi K, Rockenstein E, Crailsheim K, Masliah E, Windisch M (2011) A longitudinal study of behavioral deficits in an AbetaPP transgenic mouse model of Alzheimer's disease. J Alzheimers Dis 25:231-243. CrossRef Medline

Huotari J, Helenius A (2011) Endosome maturation. EMBO J 30:34813500. CrossRef Medline

Javed H, Menon SA, Al-Mansoori KM, Al-Wandi A, Majbour NK, Ardah MT, Varghese S, Vaikath NN, Haque ME, Azzouz M, El-Agnaf OM (2016) Development of nonviral vectors targeting the brain as a therapeutic approach for Parkinson's disease and other brain disorders. Mol Ther 24: 746-758. CrossRef Medline

Kim C, Rockenstein E, Spencer B, Kim HK, Adame A, Trejo M, Stafa K, Lee HJ, Lee SJ, Masliah E (2015) Antagonizing neuronal toll-like receptor 2 prevents synucleinopathy by activating autophagy. Cell Rep 13:771-782. CrossRef Medline

Klebe RJ, Ruddle FH (1969) Neuroblastoma: cell culture analysis of a differentiating stem cell system. J Cell Biol 43:69a.

Komarova NL, Thalhauser CJ (2011) High degree of heterogeneity in Alzheimer's disease progression patterns. PLoS Comput Biol 7:e1002251. CrossRef Medline

Lam B, Masellis M, Freedman M, Stuss DT, Black SE (2013) Clinical, imaging, and pathological heterogeneity of the Alzheimer's disease syndrome. Alzheimers Res Ther 5:1. CrossRef Medline

Larson ME, Sherman MA, Greimel S, Kuskowski M, Schneider JA, Bennett DA, Lesné SE (2012) Soluble alpha-synuclein is a novel modulator of Alzheimer's disease pathophysiology. J Neurosci 32:10253-10266. CrossRef Medline

Li J, Kanekiyo T, Shinohara M, Zhang Y, LaDu MJ, Xu H, Bu G (2012) Differential regulation of amyloid-beta endocytic trafficking and lysosomal degradation by apolipoprotein $\mathrm{E}$ isoforms. J Biol Chem 287:4459344601. CrossRef Medline

Lippa CF, Duda JE, Grossman M, Hurtig HI, Aarsland D, Boeve BF, Brooks DJ, Dickson DW, Dubois B, Emre M, Fahn S, Farmer JM, Galasko D, Galvin JE, Goetz CG, Growdon JH, Gwinn-Hardy KA, Hardy J, Heutink P, Iwatsubo T, et al.; DLB/PDD Working Group (2007) DLB and PDD boundary issues: diagnosis, treatment, molecular pathology, and biomarkers. Neurology 68:812-819. CrossRef Medline

Lucin KM, Wyss-Coray T (2013) Targeting autophagy for disease therapy. Nat Biotechnol 31:322-323. CrossRef Medline

MacLeod DA, Rhinn H, Kuwahara T, Zolin A, Di Paolo G, MacCabe BD, Marder KS, Honig LS, Clark LN, Small SA, Abeliovich A (2013) RAB7L1 interacts with LRRK2 to modify intraneuronal protein sorting and Parkinson's disease risk. Neuron 77:425-439. CrossRef Medline

Masliah E, Iwai A, Mallory M, Uéda K, Saitoh T (1996) Altered presynaptic protein NACP is associated with plaque formation and neurodegeneration in Alzheimer's disease. Am J Pathol 148:201-210. Medline

Masliah E, Rockenstein E, Veinbergs I, Mallory M, Hashimoto M, Takeda A, Sagara Y, Sisk A, Mucke L (2000) Dopaminergic loss and inclusion body formation in alpha-synuclein mice: implications for neurodegenerative disorders. Science 287:1265-1269. CrossRef Medline

Masliah E, Rockenstein E, Veinbergs I, Sagara Y, Mallory M, Hashimoto M, Mucke L (2001) beta-amyloid peptides enhance alpha-synuclein accumulation and neuronal deficits in a transgenic mouse model linking Alzheimer's disease and Parkinson's disease. Proc Natl Acad Sci U S A 98: 12245-12250. CrossRef Medline

Masliah E, Rockenstein E, Mante M, Crews L, Spencer B, Adame A, Patrick C, Trejo M, Ubhi K, Rohn TT, Mueller-Steiner S, Seubert P, Barbour R, McConlogue L, Buttini M, Games D, Schenk D (2011) Passive immunization reduces behavioral and neuropathological deficits in an alphasynuclein transgenic model of Lewy body disease. PLoS One 6:e19338. CrossRef Medline

Mattsson N, Schott JM, Hardy J, Turner MR, Zetterberg H (2016) Selective vulnerability in neurodegeneration: insights from clinical variants of Alzheimer's disease. J Neurol Neurosurg Psychiatry. In press. CrossRef

McKeith IG (2006) Consensus guidelines for the clinical and pathologic diagnosis of dementia with Lewy bodies (DLB): report of the Consortium on DLB International Workshop. J Alzheimers Dis 9:417-423. Medline

Morrison JH, Hof PR (2002) Selective vulnerability of corticocortical and hippocampal circuits in aging and Alzheimer's disease. Prog Brain Res 136:467-486. CrossRef Medline 
Nixon RA (2013) The role of autophagy in neurodegenerative disease. Nat Med 19:983-997. CrossRef Medline

Nuber S, Tadros D, Fields J, Overk CR, Ettle B, Kosberg K, Mante M, Rockenstein E, Trejo M, Masliah E (2014) Environmental neurotoxic challenge of conditional alpha-synuclein transgenic mice predicts a dopaminergic olfactory-striatal interplay in early PD. Acta Neuropathol 127:477-494. CrossRef Medline

Overk CR, Kelley CM, Mufson EJ (2009) Brainstem Alzheimer's-like pathology in the triple transgenic mouse model of Alzheimer's disease. Neurobiol Dis 35:415-425. CrossRef Medline

Overk CR, Cartier A, Shaked G, Rockenstein E, Ubhi K, Spencer B, Price DL, Patrick C, Desplats P, Masliah E (2014) Hippocampal neuronal cells that accumulate alpha-synuclein fragments are more vulnerable to Abeta oligomer toxicity via mGluR5-implications for dementia with Lewy bodies. Mol Neurodegener 9:18. CrossRef Medline

Palop JJ, Chin J, Roberson ED, Wang J, Thwin MT, Bien-Ly N, Yoo J, Ho KO, Yu GQ, Kreitzer A, Finkbeiner S, Noebels JL, Mucke L (2007) Aberrant excitatory neuronal activity and compensatory remodeling of inhibitory hippocampal circuits in mouse models of Alzheimer's disease. Neuron 55:697-711. CrossRef Medline

Peric A, Annaert W (2015) Early etiology of Alzheimer's disease: tipping the balance toward autophagy or endosomal dysfunction? Acta Neuropathol 129:363-381. CrossRef Medline

Perrett RM, Alexopoulou Z, Tofaris GK (2015) The endosomal pathway in Parkinson's disease. Mol Cell Neurosci 66:21-28. CrossRef Medline

Piao YS, Wakabayashi K, Hayashi S, Yoshimoto M, Takahashi H (2000) Aggregation of alpha-synuclein/NACP in the neuronal and glial cells in diffuse Lewy body disease: a survey of six patients. Clin Neuropathol 19:163-169. Medline

Popescu A, Lippa CF, Lee VM, Trojanowski JQ (2004) Lewy bodies in the amygdala: increase of alpha-synuclein aggregates in neurodegenerative diseases with tau-based inclusions. Arch Neurol 61:1915-1919. Medline

Reddy PH, Mani G, Park BS, Jacques J, Murdoch G, Whetsell W Jr, Kaye J, Manczak M. Differential loss of synaptic proteins in Alzheimer's disease: implications for synaptic dysfunction. J Alzheimers Dis 7:103-117, 2005; discussion 173-180.

Rockenstein E, Mallory M, Mante M, Sisk A, Masliaha E (2001) Early formation of mature amyloid-beta protein deposits in a mutant APP transgenic model depends on levels of Abeta(1-42). J Neurosci Res 66: 573-582. CrossRef Medline

Rockenstein E, Mante M, Alford M, Adame A, Crews L, Hashimoto M, Esposito L, Mucke L, Masliah E (2005) High beta-secretase activity elicits neurodegeneration in transgenic mice despite reductions in amyloid-beta levels: implications for the treatment of Alzheimer disease. J Biol Chem 280:32957-32967. CrossRef Medline

Saxena S, Caroni P (2011) Selective neuronal vulnerability in neurodegenerative diseases: from stressor thresholds to degeneration. Neuron 71: 35-48. CrossRef Medline

Schellenberg GD (1995) Genetic dissection of Alzheimer disease, a heterogeneous disorder. Proc Natl Acad Sci U S A 92:8552-8559. CrossRef Medline

Schliebs R, Arendt T (2011) The cholinergic system in aging and neuronal degeneration. Behav Brain Res 221:555-563. CrossRef Medline

Spencer B, Potkar R, Trejo M, Rockenstein E, Patrick C, Gindi R, Adame A, Wyss-Coray T, Masliah E (2009) Beclin 1 gene transfer activates autophagy and ameliorates the neurodegenerative pathology in alphasynuclein models of Parkinson's and Lewy body diseases. J Neurosci 29: 13578-13588. CrossRef Medline

Spillantini MG, Goedert M (2016) Synucleinopathies: past, present and future. Neuropathol Appl Neurobiol 42:3-5. CrossRef Medline

Swirski M, Miners JS, de Silva R, Lashley T, Ling H, Holton J, Revesz T, Love S (2014) Evaluating the relationship between amyloid-beta and alphasynuclein phosphorylated at Ser129 in dementia with Lewy bodies and Parkinson's disease. Alzheimers Res Ther 6:77. CrossRef Medline

Takeda A, Mallory M, Sundsmo M, Honer W, Hansen L, Masliah E (1998) Abnormal accumulation of NACP/a-synuclein in neurodegenerative disorders. Am J Pathol 152:367-372. Medline

Tateno F, Sakakibara R, Kawai T, Kishi M, Murano T (2012) Alphasynuclein in the cerebrospinal fluid differentiates synucleinopathies (Parkinson Disease, dementia with Lewy bodies, multiple system atrophy) from Alzheimer disease. Alzheimer Dis Assoc Disord 26:213-216. CrossRef Medline
Tiscornia G, Singer O, Verma IM (2006) Design and cloning of lentiviral vectors expressing small interfering RNAs. Nat Protoc 1:234-240. CrossRef Medline

Tsigelny IF, Crews L, Desplats P, Shaked GM, Sharikov Y, Mizuno H, Spencer B, Rockenstein E, Trejo M, Platoshyn O, Yuan JX, Masliah E (2008) Mechanisms of hybrid oligomer formation in the pathogenesis of combined Alzheimer's and Parkinson's diseases. PLoS One 3:e3135. CrossRef Medline

Tsigelny IF, Sharikov Y, Kouznetsova VL, Greenberg JP, Wrasidlo W, Gonzalez T, Desplats P, Michael SE, Trejo-Morales M, Overk CR, Masliah E (2014) Structural diversity of Alzheimer's disease: amyloid-beta dimers and their role in oligomerization and fibril formation. J Alzheimers Dis 39:583-600. CrossRef Medline

Ubhi K, Rockenstein E, Mante M, Inglis C, Adame A, Patrick C, Masliah E (2010) Alpha-synuclein deficient mice are resistant to toxin-induced multiple system atrophy. Neuroreport 21:457-462. CrossRef Medline

Ubhi K, Rockenstein E, Vazquez-Roque R, Mante M, Inglis C, Patrick C, Adame A, Fahnestock M, Doppler E, Novak P, Moessler H, Masliah E (2013) Cerebrolysin modulates pronerve growth factor/nerve growth factor ratio and ameliorates the cholinergic deficit in a transgenic model of Alzheimer's disease. J Neurosci Res 91:167-177. CrossRef Medline

van Hooft JA, Giuffrida R, Blatow M, Monyer H (2000) Differential expression of group I metabotropic glutamate receptors in functionally distinct hippocampal interneurons. J Neurosci 20:3544-3551. Medline

Volpicelli-Daley LA, Gamble KL, Schultheiss CE, Riddle DM, West AB, Lee VM (2014) Formation of alpha-synuclein Lewy neurite-like aggregates in axons impedes the transport of distinct endosomes. Mol Biol Cell 25:4010-4023. CrossRef Medline

Walker L, McAleese KE, Thomas AJ, Johnson M, Martin-Ruiz C, Parker C, Colloby SJ, Jellinger K, Attems J (2015) Neuropathologically mixed Alzheimer's and Lewy body disease: burden of pathological protein aggregates differs between clinical phenotypes. Acta Neuropathol 129: 729-748. CrossRef Medline

Wang X, Huang T, Bu G, Xu H (2014) Dysregulation of protein trafficking in neurodegeneration. Mol Neurodegener 9:31. CrossRef Medline

Wang YC, Feng GY, Xia QJ, Hu Y, Xu Y, Xiong LL, Chen ZW, Wang HP, Wang TH, Zhou X (2016) Knockdown of alpha-synuclein in cerebral cortex improves neural behavior associated with apoptotic inhibition and neurotrophin expression in spinal cord transected rats. Apoptosis 21: 404-420. CrossRef Medline

Wang Y, Yu Z, Ren H, Wang J, Wu J, Chen Y, Ding Z (2015) The synergistic effect between $\beta$-amyloid(1-42) and $\alpha$-synuclein on the synapses dysfunction in hippocampal neurons. J Chem Neuroanat 63:1-5. CrossRef Medline

Wilson AC, Dugger BN, Dickson DW, Wang DS (2011) TDP-43 in aging and Alzheimer's disease: a review. Int J Clin Exp Pathol 4:147-155. Medline

Winslow AR, Moussaud S, Zhu L, Post KL, Post KL, Dickson DW, Berezovska O, McLean PJ (2014) Convergence of pathology in dementia with Lewy bodies and Alzheimer's disease: a role for the novel interaction of alphasynuclein and presenilin 1 in disease. Brain 137:1958-1970. CrossRef Medline

Woolf NJ, Milov AM, Schweitzer ES, Roghani A (2001) Elevation of nerve growth factor and antisense knockdown of TrkA receptor during contextual memory consolidation. J Neurosci 21:1047-1055. Medline

Wu C, Cui B, He L, Chen L, Mobley WC (2009) The coming of age of axonal neurotrophin signaling endosomes. J Proteomics 72:46-55. CrossRef Medline

Wu M, Hajszan T, Xu C, Leranth C, Alreja M (2004) Group I metabotropic glutamate receptor activation produces a direct excitation of identified septohippocampal cholinergic neurons. J Neurophysiol 92:1216-1225. CrossRef Medline

Zare-Shahabadi A, Masliah E, Johnson GV, Rezaei N (2015) Autophagy in Alzheimer's disease. Rev Neurosci 26:385-395. CrossRef Medline

Zwilling D, Huang SY, Sathyasaikumar KV, Notarangelo FM, Guidetti P, Wu HQ, Lee J, Truong J, Andrews-Zwilling Y, Hsieh EW, Louie JY, Wu T, Scearce-Levie K, Patrick C, Adame A, Giorgini F, Moussaoui S, Laue G, Rassoulpour A, Flik G, et al. (2011) Kynurenine 3-monooxygenase inhibition in blood ameliorates neurodegeneration. Cell 145:863-874. CrossRef Medline 